\title{
LA MÚSICA DE CARMEN, LA DE TRIANA (1938): LAS FUENTES Y EL PROCESO CREATIVO ${ }^{1}$
}

\author{
THE MUSIC OF CARMEN, LA DE TRIANA (1938): ITS SOURCES AND ITS \\ CREATIVE PROCESS
}

\author{
Rafael Fernández de Larrinoa \\ Conservatorio Profesional de Música de Getafe (Madrid) \\ bustena@gmail.com \\ ORCID ID: 0000-0001-5511-7298.
}

\begin{abstract}
Resumen
Considerada una pieza clave de la incipiente propaganda franquista, la coproducción cinematográfica hispano-alemana Carmen, la de Triana (Florián Rey, 1938), rodada en Berlín en plena guerra civil española, ha sido ampliamente escrutada desde distintos enfoques culturales y políticos. Enmarcado en el creciente interés hacia el cine por parte de la musicología española, este filme ha sido estudiado por Laura Miranda (2018 y 2021) desde una perspectiva principalmente cultural e identitaria. Nuestro estudio, en cambio, adopta un enfoque esencialmente filológico y se centra - principal, pero no exclusivamente - en la banda sonora del compositor linense José Muñoz Molleda (1905-1988) a partir del análisis de los materiales manuscritos de su fondo personal custodiados por el Centro de Documentación y Archivo (CEDOA) de la SGAE en Madrid, no estudiados hasta la fecha. El cotejo sistemático de las partituras de este fondo con la banda sonora del filme (y, en segundo plano, con su versión alemana) revela importantes cambios operados entre la fase de preproducción y su montaje final que permiten identificar importantes decisiones tomadas por el equipo artístico a lo largo de las fases intermedias. El análisis de las implicaciones de estas decisiones permitirá esclarecer y precisar algunos aspectos cruciales del proceso creativo cinematográfico de este filme, así como de su significado, tanto en el plano artístico como en el ideológico.
\end{abstract}

Palabras clave

José Muñoz Molleda (1905-1988), Florián Rey (1894-1962), Imperio Argentina (1910-2003), Juan Mostazo (1903-1938), música de cine, cine franquista, canción popular española.

${ }^{1}$ Esta investigación se realizó como Trabajo Fin de Máster en la Universidad de La Rioja en 2020. Mi agradecimiento a Elsa Calero Carramolino, Gemma Pérez Zalduondo, Ignacio Jassa Haro, Laura Miranda, Pablo Díaz Torres, Santiago Aguilar Alvear y Miguel Ángel Marín por su amable atención y a Belén Vega Pichaco por su inestimable guía.

\begin{abstract}
Considered a key piece of the incipient Francoist propaganda, the Spanish-German film co-production Carmen, la de Triana (Florián Rey, 1938), shot in Berlin during the Spanish Civil War, has been widely scrutinized from different cultural and political perspectives. Framed in the growing interest towards cinema by Spanish musicology, this film has been studied by Laura Miranda (2018 and 2021) mainly from a cultural and identity perspective. Our study, on the other hand, adopts a significant philological approach and focuses - mainly, but not exclusively - on the soundtrack written by the composer José Muñoz Molleda (19051988), based on the analysis of hitherto not studied handwritten materials from his personal collection kept by the Centro de Documentación y Archivo (CEDOA) of the Sociedad General de Autores y Editores (SGAE) in Madrid. The systematic comparison of the scores in this collection with the film's soundtrack (and with its German version) reveals important changes that took place between the pre-production phase and its final editing, which allows to identify some important decisions taken by the artistic team throughout the intermediate phases. The analysis of the implications of these decisions will make it possible to clarify and specify some crucial aspects of the cinematographic creative process of this film, as well as its meaning, both on the artistic and ideological levels.
\end{abstract}

\section{Key words}

José Muñoz Molleda (1905-1988), Florián Rey (1894-1962), Imperio Argentina (1910-2003), Juan Mostazo (1903-1938), film music, Francoist cinema, Spanish popular song. 
Carmen, la de Triana (1938), dirigida por el aragonés Florián Rey (1894-1962) y protagonizada por la estrella de la canción Imperio Argentina (1910-2003), es posiblemente uno de los títulos cinematográficos españoles más estudiados y mejor documentados de su década. El interés de esta película trasciende sus valores puramente fílmicos, ${ }^{2}$ al tratarse de la primera y más importante colaboración cinematográfica entre el incipiente régimen franquista y la Alemania nazi y haber sido aprobada - si no instigada - por el mismísimo Adolf Hitler. ${ }^{3}$ También es el más ambicioso, desde el punto de vista artístico, de los cinco filmes de ficción ${ }^{4}$ resultantes de la colaboración hispano-germana de este periodo, así como el más sensible en términos propagandísticos. ${ }^{5}$

El proyecto, que sería rodado simultáneamente en versión española y alemana, ${ }^{6}$ apoyado y supervisado por el mi-

\footnotetext{
${ }^{2}$ Las circunstancias del rodaje de Carmen, la de Triana inspiraron la película La niña de tus ojos (1998) de Fernando Trueba.

3 Marta Muñoz Aunión, "El cine español según Goebbels: apuntes sobre la versión alemana de Carmen, la de Triana”, en El espiritu del caos. Representación y recepción de las imágenes durante el Franquismo, coord. Laura Gómez Vaquero y Daniel Sánchez Salas (Madrid: Ocho y Medio, 2009), pp. 29-30.

${ }^{4}$ Estos filmes son: Carmen, la de Triana, El barbero de Sevilla (Benito Perojo, 1938), Suspiros de España (Benito Perojo, 1938), Mariquilla terremoto (Benito Perojo, 1939) y La canción de Aixa (Florián Rey, 1939).

${ }^{5}$ Los aspectos políticos y comerciales de esta asociación
} han sido estudiados por: Aitor Yraola, “'Misión españolista': los camaradas Florián e Imperio con Hitler y el Dr. Goebbels", FILMHISTORIA Online, 9/3 (1999) <https://revistes.ub.edu/index. php/filmhistoria/article/view/12380> [consulta: 18/01/2020]; Emeterio Díez Puertas, "Los acuerdos cinematográficos entre el franquismo y el Tercer Reich (1936-1945)", Archivos de la Filmoteca. Revista de estudios históricos sobre la imagen. Segunda época, 33 (1999), pp. 34-59; del mismo autor, "El montaje del Franquismo: la política cinematográfica de las fuerzas sublevadas", Cuadernos de Historia Contemporánea, 23 (2001), pp. 141-157; Manuel Nicolás Meseguer, La intervención velada: el apoyo cinematográfico alemán al bando franquista (19361939) (Murcia: Universidad de Murcia, 2004); del mismo autor, Hispano Film Produktion. Una aventura españolista en el cine del Tercer Reich (1936-1944) (Santander: Shangrila, 2017); y Marta Muñoz Aunión, "El cine español según Goebbels: apuntes sobre la versión alemana de Carmen, la de Triana”, en El espíritu del caos. Representación y recepción de las imágenes durante el Franquismo, coord. Laura Gómez Vaquero y Daniel Sánchez Salas (Madrid: Ocho y Medio, 2009), pp. 21-62.

${ }^{6}$ La versión alemana, titulada Andalusische Nächte y dirigida por Herbert Maisch, remplazó el reparto español por uno nistro de Propaganda Joseph Goebbels, tuvo entre sus principales objetivos la conquista del mercado cinematográfico de habla hispana. ${ }^{7}$ Para ello, se pretendió emular el extraordinario éxito cosechado en el mercado latinoamericano por el tándem Rey/Argentina gracias al folclorismo andaluz de Morena clara (1936), ${ }^{8}$ una fórmula que fue adoptada en cuatro de las cinco producciones hispano-germanas, en las que sus protagonistas - Argentina en unas y Estrellita Castro en otras - encarnaron a artistas sevillanas de etnia gitana.

La propuesta original de la Cancillería del Reich y el Ministerio de Propaganda alemán, presentada a la Universum Film AG (UFA) el 4 de junio de 1937, consistía en el rodaje de una adaptación de la ópera Carmen con Imperio Argentina como protagonista y Florián Rey como director. No obstante, ante la imposibilidad de utilizar la música de Bizet — cuyos derechos eran propiedad de la productora estadounidense Paramount-, se optó por encargar una nueva partitura a un compositor español, ${ }^{9}$ responsabilidad que recayó en el sevillano Juan Mostazo (1903-1938) y el linense José Muñoz Molleda (1905-1988). ${ }^{10}$ La elección de Mostazo como autor de las canciones puede considerarse obvia, dado el éxito cosechado anteriormente junto a Rey y Argentina en Morena clara. ${ }^{11}$ Por su parte, Muñoz Molleda acababa de culminar un pensionado que el Gobierno español le había otorgado en 1934 para una estancia de cuatro años en la Academia de Bellas Artes de Roma, durante la cual estudió con Ottorino Respighi. ${ }^{12}$ En tanto que debutante en el medio

enteramente alemán a excepción de Imperio Argentina, que protagonizó ambas.

7 Díez Puertas, "Los acuerdos cinematográficos", p. 38.

8 Jo Labanyi, Lo andaluz en el cine del franquismo: los estereotipos como estrategia para manejar la contradicción (Sevilla: Fundación Centro de Estudios Andaluces, centrA, 2003), p. 2: "Aquí es importante recordar que el género folklórico fue inventado y promovido originalmente bajo la II República, cuando su máxima estrella, Imperio Argentina, atrajo un público más numeroso que el cine de Hollywood".

9 Muñoz Aunión, "El cine español según Goebbels”, pp. 33-34.

10 José Muñoz Molleda, nacido en La Línea de la Concepción el 16 de febrero de 1905, estudió composición con Conrado del Campo en el Conservatorio de Madrid.

${ }^{11}$ Las canciones del film Morena clara fueron "Échale guindas al pavo", "Falsa moneda" (ambas con letra de Ramón Perelló y Sixto Cantabrana) y "El día que nací yo", con letra de Antonio Quintero y Pascual Guillén.

12 Gemma Pérez Zalduondo, El compositor José Muñoz Molleda: de la Generación del 27 al franquismo (Almería: Zéjel Editores, 1989), p. 40. 
cinematográfico, no es fácil determinar las razones que indujeron a encargar a Muñoz Molleda la confección de la banda sonora, aunque los lazos artísticos y de paisanaje que lo unían con Imperio Argentina permiten aventurar a ésta como artífice o avalista de su reclutamiento. ${ }^{13}$

Esta elección pudo contar con algún tipo de conformidad por parte de Rey, quien no debió sentirse cómodo con el plan original de llevar al cine la ópera de Bizet y aprovechó la oportunidad brindada por las autoridades culturales nazis para reescribir este mito hispánico de alcance mundial de acuerdo con una visión "auténtica" y alejada de los tópicos de la espagnolade ${ }^{14}$ Este propósito no se habría alcanzado de forma plena sin la decidida intervención en la parte musical por parte del director de cine aragonés, quien ya había actuado como artífice de la reorientación de la carrera artística de Imperio Argentina hacia el musical folclórico. ${ }^{15}$ Como veremos a lo largo del estudio, la peculiar simbiosis entre Carmen, la de Triana y su banda sonora contrasta con el rutinario tratamiento de la parte musical de su contraparte alemana, ${ }^{16}$ cuya partitura replica los materiales provistos por Mostazo y Muñoz Molleda con contadas - pero muy ilustrativasadaptaciones. ${ }^{17}$

13 Imperio Argentina había llevado al disco entre los años 1932 y 1933 algunas de las canciones de Muñoz Molleda. Pérez Zalduondo, El compositor José Muñoz Molleda, pp. 36-37, sugiere que fue la experiencia con la música ligera la que le puso en contacto con el cine sonoro. Por otra parte, el origen linense del compositor y gibraltareño - por parte de padrede Imperio Argentina sustentan la hipótesis de una relación de paisanaje. Los padres de la artista vivieron, desde principios de los años treinta, en una finca que habían comprado en La Línea de la Concepción. Véase Martín de la Plaza, Imperio Argentina. Una vida de artista (Madrid: Alianza Editorial, 2003), p. 79.

${ }^{14}$ Esta tesis es desarrollada en Laura Miranda, "A new Carmen for a new Spain: nationalism and cinema during the Spanish Civil War", en Experiencing Music and Visual Cultures. Threshold, Intermediality, Synchresis, ed. Antonio Cascelli y Denis Condon (Abingdon: Routledge, 2021), pp. 91-103.

${ }^{15} \mathrm{El}$ ambiente musical en el que se formó Rey, así como el sustrato folclórico del cine de la pareja Rey/Argentina están caracterizados en Laura Miranda, Canciones en el cine español. Periodo de autarquía (1939-1950) (Santander, Shangrila, 2018), pp. 77-96, "El cine de Florián e Imperio: de Morena clara a Carmen, la de Triana".

${ }^{16}$ Las desviaciones más importantes de la edición de la partitura de Muñoz Molleda realizada por Hansom Milde-Meissner (1899-1983) para la versión alemana serán comentadas a lo largo de este estudio.

${ }^{17}$ La comparación de la película de Rey con El barbero de

\section{BASES PARA EL ESTUDIO DE LA MÚSICA DE CARMEN, LA DE TRIANA}

Carmen, la de Triana ha despertado un gran interés desde los ámbitos cinematográfico, ${ }^{18}$ político ${ }^{19} \mathrm{y}$ de los estudios culturales..$^{20} \mathrm{~A}$ ello se han sumado recientemente los estudios musicológicos ya citados de Laura Miranda: el primero, consagrado a las canciones de Mostazo y, el segundo, centrado en la contribución de la música a los aspectos identitarios del filme. ${ }^{21}$ Más allá de Carmen, la de Triana, la música cinematográfica de Muñoz Molleda ha sido estudiada de nuevo por Miranda y por Esther García Soriano en un momento de creciente interés por esta materia por parte de la musicología española. ${ }^{22}$

Sevilla de Benito Perojo — rodada en Berlín ese mismo año y acompañada de una banda sonora confeccionada a partir de la partitura rossiniana-resulta igualmente reveladora del celo musical del director aragonés frente al desentendimiento del madrileño.

18 Véanse, por ejemplo: Agustín Sánchez Vidal, El cine de Florián Rey (Zaragoza: Caja de Ahorros de la Inmaculada, 1991); Sylvia Zierer Meliá, "Carmen la de Triana”, en Antología crítica del cine español, ed. Julio Pérez Perucha (Madrid: Filmoteca Española / Cátedra, 1997), pp. 116-118; Rafael Jover Oliver, "Andalucía desde Berlín: Carmen la de Triana", en Andalucía: una civilización para el cine, coord. Francisco Perales Bazo (Sevilla: Padilla libros, 2001), pp. 13-34; y, del mismo autor, "Una 'Carmen' alemana. El cine español y la Alemania nazi”, mAGAzin. Revista de Germanística Intercultural, 11 (2002), pp. 74-81.

19 Véanse Juan Miguel Company, "La cruzada del brigadier", Archivos de la Filmoteca de la Generalitat Valenciana, 7 (1990), pp. 14-19; y Muñoz Aunión, "El cine español según Goebbels".

${ }^{20}$ Véanse Jo Labanyi, Lo andaluz en el cine del franquismo: los estereotipos como estrategia para manejar la contradicción (Sevilla: Fundación Centro de Estudios Andaluces, centrA, 2003); Trinidad Pardo Ballester, "Flamenco: orientalismo, exotismo y la identidad nacional española", tesis doctoral, Washington, Georgetown University, 2007; José María Claver Esteban, Luces y rejas. Estereotipos andaluces en el cine costumbrista español (1896-1939) (Sevilla: Fundación Pública Andaluza Centro de Estudios Andaluces, 2012); y Eva Woods Peiró, White Gypsies. Race and Stardom in Spanish Musicals (Minneapolis y Londres: University of Minnesota Press, 2012).

${ }^{21}$ Miranda, "El cine de Florián e Imperio" y "A new Carmen for a new Spain".

${ }^{22}$ Laura Miranda, "La música en el cine policiaco de Edgar Neville. Del cosmopolitismo hollywoodiense al casticismo de posguerra. Propuesta de análisis audiovisual", Revista de 
El estudio de las fuentes musicales - y las partituras mismas - ocupa un lugar subsidiario o nulo en la mayoría de los estudios dedicados a la música del cine, incluidos los musicológicos. En muchos casos - especialmente, en el cine español anterior a los años 1980-, se debe a que los materiales originales son en su mayoría inexistentes o ilocalizables. Pero incluso en los casos en los que la partitura de una película constituye una fuente declarada del estudio, apenas suele aportar algo distinto a lo que se puede escuchar directamente en el filme. ${ }^{23}$

Carmen, la de Triana reúne condiciones excepcionales para su estudio desde el punto de vista musical porque cuenta con un abundante material manuscrito en el Centro de Documentación y Archivo de la SGAE (como parte del Fondo José Muñoz Molleda) que incluye un guion musical completo de la banda sonora. ${ }^{24}$ Además, existen enormes divergencias entre el guion musical y la música recogida en la película, lo que convierte este material en una fuente crucial para trazar un proceso creativo complejo y sinuoso que, de otra manera, habría sido imposible de reconstruir, dada la imposibilidad de acceder al guion cinematográfico original. ${ }^{25}$ Para evaluar en detalle estas divergencias hemos editado una copia digital del fil-

Musicología, 32/ 2 (2009), pp. 687-702. La tesis doctoral de Esther García Soriano, La música en el cine español de la posguerra (1939-1950), tesis doctoral, Universidad Complutense de Madrid, 2014, pp. 631-644, incluye un análisis estilístico de la música de cine de Muñoz Molleda compuesta entre 1939 y 1950. Véase también Teresa Fraile, "Música de cine en España. Crecimiento y consolidación de una disciplina", La Albolafia. Revista de Humanidades y Cultura, 9 (2016), pp. 11-30.

${ }^{23}$ La excepción más significativa a esta regla en el ámbito español sigue siendo la iniciativa de restauración del repertorio cinematográfico histórico llevada a cabo por el compositor José Nieto en los años 1990. De este esfuerzo, auspiciado por la Fundación Autor, resultaron tres ediciones discográficas consagradas a Juan Quintero (1998), Jesús García Leoz (1999) y Manuel Parada (2000), respectivamente, que contaron con sendas notas biográficas y analíticas de Julio Arce.

${ }^{24}$ El guion musical consiste en una versión preliminar pianística a dos o tres pentagramas con algunas indicaciones relativas a la orquestación.

${ }^{25}$ El guion cinematográfico original —es decir, el que debió utilizar Muñoz Molleda como base para la composición del manuscrito MMolleda $\backslash 034$ - parece estar perdido o descatalogado. La Filmoteca Nacional custodia únicamente, como "Florián Rey. Carmen, la de Triana [Guion - Lista de diálogos]" (signatura G-8777), una traducción al inglés mecanografiada de la versión definitiva, probablemente destinada a de ser utilizada para el subtitulado o el doblaje. me, sobreimponiendo la partitura de Muñoz Molleda en el cuarto inferior derecho de la pantalla en sincronía con ésta, mediante la aplicación informática iMovie. La sincronización de la partitura con la película nos ha servido para localizar de forma precisa las desviaciones existentes entre el guion musical y la banda sonora definitiva, proporcionándonos los elementos sobre los que fundamentar nuestras hipótesis acerca de los cambios operados entre la fase de preproducción y montaje, así como de su significado fílmico.

En paralelo a esta tarea, hemos recopilado y contrastado información dispersa relativa a los aspectos musicales del filme, recurriendo a diversas fuentes bibliográficas y hemerográficas, con el objeto de esbozar una cronología y las circunstancias del proceso creativo y, de forma particular, trazar el origen incierto de las canciones de Mostazo. Del mismo modo, hemos recurrido también a las ediciones pianísticas comerciales de las canciones del filme y a sus registros fonográficos (Apéndice 3), así como a las películas Carmen, la de Triana y su versión alemana, Andalusische Nächte, de la que comentaremos las desviaciones más destacables observadas en el plano musical. ${ }^{26}$

\section{EL PROCESO CREATIVO DE CARMEN, LA DE TRIANA}

Son varias las pistas que advierten que el guion musical conservado en el manuscrito MMolleda\034 fue compuesto en la fase de preproducción del filme, es decir, tomando como referencia el guion cinematográfico y no las escenas ya rodadas o premontadas. Esta hipótesis explica las cuantiosas discordancias que la música del manuscrito exhibe con respecto a la versión recogida en la película, y que no se habrían producido de haber sido compuesta en la fase de posproducción. ${ }^{27}$ Estas discor-

${ }^{26}$ He utilizado la edición comercial de Carmen, la de Triana, publicada en 2014 en DVD y Blu-ray por Mercury Films y Divisa Home Video, también disponible en plataformas digitales como FlixOlé. De acuerdo con el artículo "Carmen, la de Berlín" (18-11-2018), firmada mediante seudónimo, esta edición incluye algunos breves cortes y alteraciones del encuadre con el fin de evitar los fotogramas más dañados; véase $<$ http:// documentitosdeunindocumentado.blogspot.com/2018/11/carmen-la-de-berlin.html $>$ [consulta 12/6/2020]. Los minutajes incluidos a lo largo de este trabajo están referidos a esta edición. Actualmente no hay disponible ninguna copia comercial de la versión alemana, Andalusische Nächte, de esta película.

27 Estas discordancias tienen lugar en forma de cortes, repeticiones o añadidos. Aparte de estas formas de edición, no 
dancias se habrían debido a que, una vez consolidadas las escenas durante el rodaje (con los oportunos descartes y añadidos) y efectuado el premontaje, el compositor se habría visto obligado a aplicar diversos retoques - cortes, repetición o adición de nuevos compases $-{ }^{28}$ y preparar la orquestación de la versión final para la ulterior grabación de la banda sonora, ya en sincronía con el montaje final. ${ }^{29}$

La supresión del bloque musical $\mathrm{n}^{\circ} 10 \mathrm{del}$ manuscrito de Muñoz Molleda para la secuencia taurina (que estudiaremos en el apartado 4.2.6) aporta una referencia cronológica de especial valor, dado que el rodaje de los exteriores en suelo español tuvo lugar unos meses antes del inicio de la filmación en los estudios de Berlín. ${ }^{30}$ Dado que el rodaje de las escenas de la corrida de toros tuvo lugar en La Maestranza de Sevilla el 7 de octubre de $1937^{31}$ y la propuesta oficial de rodar una película sobre Carmen se produjo el 4 de junio, el manuscrito MMolleda $\backslash 034$ - que incluye la secuencia musical para este episodio finalmente descartada - podría así haber sido escrito entre estas dos fechas.

Los desajustes entre el guion musical y la partitura final no deberían atribuirse a una falta de planificación de Rey; la precisión con la que el guion musical de Muñoz Molleda anota y dimensiona las escenas parece corroborar un alto grado de concreción del guion cinematográfico del director aragonés. De acuerdo con Imperio Argentina, "Florián, preparaba las películas, con mucho tiempo". ${ }^{32}$ Refiriéndose a Nobleza baturra, explica:

se producen cambios que afecten a las líneas melódicas y la armonía establecida en el guion musical.

28 A este respecto, Muñoz Molleda declaró que "él fue muy apreciado por los directores y productores por su capacidad para adaptar en poco tiempo una partitura ya escrita, a cambios imprevistos que durante el rodaje alteraban la duración, el contenido, etc., de una escena."; véase Pérez Zalduondo, El compositor José Muñoz Molleda, p. 90.

${ }^{29}$ Contrasta este sistema con el proceso predominante en España - más económico, pero lesivo en términos de calidad artística-, consistente en componer la partitura una vez filmada y premontada la película; véase López González, Música y cine en la España del franquismo, pp. 307-308.

30 Según Muñoz Aunión, "El cine español según Goebbels", pp. 37-38, el rodaje en los estudios berlineses comenzó a finales de enero de 1938 y se extendió durante cuarenta y cinco días.

31 Del rodaje de estas escenas, con la presencia de Imperio Argentina, da cuenta la prensa local; véase $A B C$ (Sevilla, 8 de octubre de 1937), p. 15.

32 José Ruiz y Jorge Fiestas, Imperio Argentina. Ayer hoy y siempre (Sevilla: Argantonio. Ediciones Andaluzas, 1981), p. 44. en el cine ocurre igual, tienes que convivir, con la película, mientras la preparas. Nosotros invitábamos a los compañeros a casa y discutíamos horas y horas. Muchos días hasta la madrugada. Hablando y cambiando impresiones, sobre lo que íbamos a hacer, luego, localizábamos por nuestra cuenta [...] A mí, muchas veces, me decía, Florián: 'Nusca - me llamaba Nusca- ¿Qué te parece este plano aquí?'. Otras veces, las sugerencias eran mías. ${ }^{33}$

Con respecto a Carmen, la de Triana, Rey habría comenzado a trabajar en París, ${ }^{34}$ probablemente en mayo de 1937, ${ }^{35}$ mientras Imperio y él se documentaban sobre Lola Montes, protagonista de una propuesta cinematográfica sugerida por Goebbels que sería finalmente descartada. ${ }^{36}$

Ahora bien, en el caso de Rey, la realización de un filme no consistía en una mera ejecución del guion. En una entrevista realizada con motivo del décimo aniversario de Morena clara, el director revela otra faceta del proceso creativo: el ajuste sobre la marcha: ${ }^{37}$

- Porque, Morena Clara se rodó así, con estas improvisaciones. Es más, se rodó sin que nadie escribiese el guion y sin que hubiese orden de trabajo.

A la hora del desayuno, Florián hacía los diálogos complementarios de la película, que dictaba al mismo tiempo y que debían de aprenderse los intérpretes a continuación. Todo a esta presión de tiempo y con la buena fortuna de las cosas que han de salir bien. ${ }^{38}$

${ }^{33}$ Ruiz y Fiestas, Imperio Argentina, p. 60.

34 El proyecto de Carmen pudo flotar en el ambiente desde mucho antes de la expedición parisina. El 13 de agosto de 1936, el corresponsal en la Bienal de Venecia de Film-Kurier se rendía al "nervio irresistible" de Imperio Argentina: "Rodar Carmen con esta mujer debe ser un acontecimiento"; véase Rosa Álvarez Berciano y Ramón Sala Noguer, El cine en la zona nacional (1936-1939) (Bilbao: Ediciones Mensajero, 2000), p. 225.

35 De la Plaza, Imperio Argentina, p. 110, afirma que el paréntesis parisino habría tenido lugar "después de tres meses de estancia en Berlín [...] en primavera". Sin embargo, según Muñoz Aunión, "El cine español según Goebbles”, pp. 30 y 33), y de acuerdo con las actas de la cancillería del Reich, Rey y Argentina desembarcaron en Bremen el 2 de abril de 1937, y la propuesta oficial de rodar una película sobre Carmen se produjo de vuelta de París en Berlín el 4 de junio. De este modo, estos "tres meses" apenas debieron alcanzar uno y la estancia en París habría tenido lugar hacia el mes de mayo.

${ }^{36}$ De la Plaza, Imperio Argentina, p. 110.

37 "Diez años después de Morena clara, entrevista a Florián Rey”, Primer plano. Revista española de cinematografía, año V, núm. 174 (Madrid, 13 de febrero de 1944), p. 8.

${ }^{38} \mathrm{La}$ sorprendente falta de planificación con respecto a los 
Para Rey, la improvisación no contradice ni desvirtúa la planificación, solo constituye una fase distinta. En otra entrevista justifica la "creación sobre la marcha" como un momento indispensable del proceso creativo y le atribuye un carácter idiosincrático con respecto a su forma de entender el cine:

Mire usted: el principal defecto que se me ha achacado es que creo sobre la marcha [...] Pero... ¿cómo no voy a hacerlo? Entiendo yo que el trabajo de dirección es eso: creación sobre la marcha. Si sobre la marcha veo una novedad a intercalar, ¿cómo no voy a hacerlo? Yo nunca estoy satisfecho..... ${ }^{39}$

Esta doble vertiente del proceso creativo del cine de Florián Rey —el celo planificador y la libertad para subvertir lo planificado- explicaría tanto la precisión del guion musical de Muñoz Molleda como la profundidad de los cambios operados hasta llegar a la partitura final, obligada a adaptarse a un proyecto en permanente evolución. Es precisamente esta cualidad la que convierte al manuscrito MMolleda 034 en un elocuente testimonio del proceso creativo de este filme.

\section{LAS CANCIONES DE JUAN MOSTAZO Y LA MUERTE DE "ANTONIO VARGAS HEREDIA"}

Las películas de Rey y Argentina se inscriben en el género musical, especialidad que encontró en la "zarzuela filmada" uno de sus principales filones durante la década de $1930 .{ }^{40} \mathrm{La}$ eficacia de esta fórmula comercial, consistente en utilizar como reclamo la popularidad de números musicales bien conocidos por el público, se aplicó en algunos casos puntuales al género canzonetístico. ${ }^{41}$

diálogos que revela esta entrevista no es tal si tenemos en cuenta que Morena clara, al derivar de una obra teatral, contaba de antemano con diálogos escritos que fueron adaptados sobre la marcha. Es improbable que Rey procediera de forma semejante con Carmen, la de Triana.

39 Domingo Barreira, Biografia de Florián Rey (Madrid: Agrupación Sindical de Directores-Realizadores Españoles de Cinematografía, 1968), pp. 52-53.

40 Román Gubern, El cine sonoro en la II República 19291936. Historia del cine español II (Barcelona, Editorial Lumen, 1977), p. 117.

${ }^{41}$ Es el caso de: El relicario (Ricardo de Baños, 1933), basada en la canción-pasodoble homónima con música de José Padilla y letra de Armando Oliveros y José María Castellví compuesta en 1914; La hija de Juan Simón (José Luis Sáenz de Heredia, 1935), basada en la milonga con música de Daniel Montorio y letra de
Sin embargo, el cine de Rey y Argentina operó en sentido contrario a estos ejemplos, pues en vez de tomar prestados éxitos musicales preexistentes, se convirtió en el trampolín comercial de títulos como las "Sevillanas Imperio" (La hermana San Sulpicio, 1934) o "Falsa moneda" (Morena clara, 1936). ${ }^{42}$ Con respecto a lo discutido con anterioridad, la composición in situ de "El día que nací yo" por parte de Mostazo, a partir de un recitado extraído de la comedia de Antonio Quintero y Pascual Guillén, aportaría un ejemplo extremo de solapamiento entre el proceso creativo fílmico y musical. ${ }^{43}$

A diferencia del procedimiento habitual en las películas producidas en España, las canciones de Carmen, la de Triana fueron grabadas previamente a su filmación, ${ }^{44}$ hecho que permitió a Imperio Argentina rodar las escenas en playback. ${ }^{45}$ Además, mientras las canciones de Morena

Mauricio Torres García; María de la O (Francisco Elías, 1936), basada en la zambra con música de Manuel López-Quiroga y letra de Salvador Valverde y Rafael de León compuesta en 1933; y Suspiros de España (Benito Perojo, 1939), basada en el pasodoble con música de Antonio Álvarez Alonso compuesto en 1902 y cuya letra fue añadida en 1938 por José Antonio Álvarez Cantos, sobrino del compositor, para dicho filme.

${ }^{42}$ Rey se vanagloriaba de este hecho al proclamar haber descubierto al mundo el talento del compositor Juan Mostazo: "Yo descubrí un músico. Creo que los directores se felicitan cuando lanzan una estrella o un astro de primera magnitud. El caso de Mostazo en Morena clara se puede comparar a estos descubrimientos"; véase "Diez años después de Morena clara", p. 7.

43 "Diez años después de Morena clara", p. 8: "Yo tenía la letra original de las canciones. De repente se me ocurrió que en la escena que estábamos impresionando debía haber una canción de Imperio. Me volví hacia Mostazo, que estaba detrás de mí, y le alargué, sin otra explicación, un papel con la letra. Él me comprendió. Se metió en un camerino para aislarse de la batahola de los Estudios, y en menos de media hora concibió y escribió la música. En tanto, febrilmente, nosotros hacíamos venir la orquesta a toda prisa; Guerner estudiaba y mandaba disponer las luces; todo el mundo tenía que aprenderse la letra, y cuando Mostazo salió del camerino con la música, 'con su música', aquello se rodó como si no hubiera pasado nada".

${ }^{44}$ Según el semanario Lichtbild-Bühne (6 de julio de 1938), recogido en Meseguer, La intervención velada, p. 140, Imperio Argentina grabó las canciones en una sala de conciertos de Berlín, hecho que le resultó muy llamativo y una demostración del nivel técnico de la industria cinematográfica alemana.

45 Esta técnica se utilizó en el cine musical estadounidense desde finales del año 1929 y era de uso generalizado en todos los grandes estudios en 1930; véase Rick Altman, The American Film Musical (Bloomington, IN: Indiana University Press, 1987), p. 151 
clara - y quizá, las de todas sus anteriores películashabrían sido compuestas en conexión directa con el rodaje del filme, en el caso de Carmen las canciones se habrían originado en circunstancias muy diversas ${ }^{46}$ de acuerdo con diversos testimonios ofrecidos por ella misma. Por un lado, la artista reivindicó tardíamente la autoría de la música de dos de las canciones del filme: las "Carceleras del Puerto" y "La muerte de Vargas Heredia", ${ }^{47}$ en un alegato que invita a un estudio en clave feminista de este asunto que cae fuera de nuestro propósito. ${ }^{48}$

Por otro lado, con respecto a otras dos canciones —acaso las más importantes del filme: las bulerías "Los piconeros" y la zambra "Antonio Vargas Heredia"- la artista aseveró que habían sido estrenadas por Miguel de Molina en Valencia "durante la guerra". ${ }^{49}$ Este dato - que no encuentra eco en la autobiografía del célebre cancionista y amigo de Imperio - ${ }^{50}$ es corroborado por el erudito de la copla Daniel Pineda Novo, quien sitúa además a Juan Mostazo en Valencia en 1937. ${ }^{51}$ La relación de letristas de las canciones de Carmen (Apéndice 4) respalda el testimonio de Imperio en el caso de "Los piconeros"; se trata, en efecto, de la única canción del filme firmada por Ramón Perelló, quien no formó parte de la comitiva berlinesa y que no habría aceptado participar en esta aventura franquista dado su firme compromiso republicano. ${ }^{52}$

${ }^{46}$ La comparación entre la música de Morena clara y Carmen arroja además enormes contrastes que reflejan las diferencias existentes entre los sistemas de producción español y alemán: la primera cuenta con música en solo un $25 \%$ de su metraje frente al $62 \%$ de la segunda, según estimaciones propias.

47 Ruiz y Fiestas, Imperio Argentina, p.44.

48 Como destinataria oficial de las canciones de esta película, Imperio Argentina pudo haber dado su forma definitiva a muchas canciones, sancionándolas mediante su interpretación. Compárese el inicio de la versión original de la canción "Triana, Triana" conservada en MMolleda 038 y MMolleda s.n. (1) con la versión definitiva recogida en el filme, en los registros fonográficos y en las ediciones impresas; véase Apéndice 2.1.

49 Ruiz y Fiestas, Imperio Argentina, p. 67.

${ }^{50}$ Miguel de Molina, Botín de Guerra. Autobiografia (Barcelona: Planeta, 1998). Esta autobiografía es, en cualquier caso, extremadamente parca en referencias a las canciones que jalonaron su carrera.

${ }^{51}$ Daniel Pineda Novo, Rafael de León, un hombre de copla (Torredonjimeno: Editorial Almuzara, 2012), p. 63.

${ }^{52}$ El unionense Ramón Perelló permaneció totalmente desconectado de la producción de Carmen dado que "con el estallido de la Guerra Civil Española, regresó a su tierra para dirigir 'Cartagena Nueva', diario de inspiración libertaria, y se convirtió en
En el caso de "Antonio Vargas Heredia", es la letra la que refuerza la tesis de su génesis republicana. En efecto, la copla es reseñable por inspirarse en dos poemas lorquianos pertenecientes al Romancero gitano (1928), ${ }^{53}$ protagonizados por Antonio Torres Heredia (un nombre casi coincidente con el del torero de la película de Rey), y que comparten con la canción del filme motivos tan característicos como la vara de mimbre, la luna, el color verde y Benamejí. Resulta improbable la planificación de esta suerte de homenaje lorquiano en un filme franquista, apenas un año después de la ejecución del poeta por los "nacionales". Por el contrario, la concepción y estreno de la copla en la "zona roja" (Valencia) y su posterior reapropiación en la película, con Mostazo como intermediario, parecen mucho más plausibles. De este modo, la independencia entre la creación de la canción con respecto a la película podría considerarse no ya una explicación, sino una condición necesaria: el desconocimiento — o emborronamiento- de su filiación lorquiana habría permitido incorporarla al filme en virtud de su autoría "oficial" — Joaquín de la Oliva y Juan Mostazo_- de su encaje con la narrativa y los valores del filme y, en última instancia, por su valor artístico. ${ }^{54}$

Sea cual fuere el origen de "Antonio Vargas Heredia", la cuestión no es baladí desde el punto de vista del proceso creativo, pues del mismo modo que la protagonista de Carmen, la de Triana resultó de la yuxtaposición de los estereotipos, hasta cierto punto incompatibles, de la locuaz gitana de Morena clara, ${ }^{55}$ del alter ego de Imperio Argentina como estrella de la canción ${ }^{56}$ y de la Magda-

uno de los poetas oficiales del anarquismo, colaborando con prensa comunista. [...] Finalizado el conflicto, Perelló fue condenado a muerte por su activa militancia antifranquista, pena conmutada por la de prisión"; véase Francisco José Ródenas Rozas, "Especial: Ramón Perelló", Revista La Flamenca, 28 (2009) <http:// www.revistalaflamenca.com/reportaje-ramon-perello/> [consulta: 20-5-2020].

53 "Prendimiento de Antoñito el Camborio en el camino de Sevilla" y "Muerte de Antoñito el Camborio".

${ }^{54}$ Según Trinidad Pardo Ballester, Flamenco: orientalismo, exotismo y la identidad nacional española, tesis doctoral, Washington, Georgetown University, 2007, vol. 1, pp. 291-316, Carmen, la de Triana habría contribuido de forma significativa a la transferencia al franquismo de una parte del discurso orientalista del modernismo español gestado durante el periodo republicano.

55 El paralelismo entre Trini de Morena clara y Carmen es desarrollado por Miranda, Canciones en el cine español, pp. 85-87.

56 Según Vicente J Benet, "Tipologías del estrellato durante el franquismo: algunas fórmulas dominantes", Cinema Compart/Ive Cinema, 5/10 (2017), pp. 29-30, Imperio Argentina 
lena sufriente del ideario nacionalcatólico, ${ }^{57}$ la figura de Antonio Vargas Heredia pudo haberse forjado a partir de la combinación del Lucas/Escamillo de Merimée/Bizet y la zambra de Oliva/Mostazo. En efecto, de esta dependen cuatro rasgos del torero de Florián Rey que lo distinguen de sus ancestros franceses: su nombre, la etnia gitana, su estancia en prisión "por culpa de una hembra gitana" y la anticipación de su muerte en el ruedo. Así, esta zambra habría sido responsable de la incorporación al mito de Carmen de un arquetipo infrecuente en la canción popular española, pero que había quedado grabado a fuego en el imaginario del cuplé desde los tiempos de "El relicario": el lance trágico en el ruedo del torero enamorado, ${ }^{58} \mathrm{del}$ que "Antonio Vargas Heredia" ha sido, ya en el ámbito de la copla andaluza, su más ilustre sucesor. ${ }^{59}$

\section{LA MÚSICA DE CARMEN, LA DE TRIANA}

\subsection{La cara oculta de la Carmen berlinesa}

El manuscrito MMolleda\034, perteneciente al Fondo José Muñoz Molleda custodiado en la SGAE, ${ }^{60}$ contiene la práctica totalidad de la música original compuesta por este autor para la banda sonora del filme ${ }^{61}$ Consta de nueve

constituye precisamente la figura más emblemática del modelo de estrellato cosmopolita, "híbrido" entre el cine y la canción, característico de las décadas de 1920-30. La identificación de la cosmovisión liberal vinculada a la ideología capitalista del estrellato subyacente en las coproducciones hispano-germanas durante la Guerra civil es una de las ideas centrales en torno a esta cuestión en Woods Peiró, White Gypsies, pp. 185-187.

57 Este es el juicio que prevalece en Claver Esteban, Luces y rejas, pp. 509-512.

${ }^{58}$ La muerte del torero - en este caso, del rejoneador Lucas - tiene también lugar en la película muda Carmen (Jacques Feyder, 1926), protagonizada por la cupletista aragonesa Raquel Meller y con música del compositor madrileño Ernesto Halffter.

${ }^{59}$ La presencia de Florián Rey en los créditos literarios de la canción (Apéndice 4) sugiere, no obstante, algún tipo de adaptación de la letra original de Joaquín de la Oliva a los requerimientos del filme, lo cual imposibilita saber con certeza cuáles fueron los rasgos del torero heredados de la letra original y cuáles los sobrevenidos.

${ }^{60}$ Muñoz Molleda mantuvo una estrecha vinculación con dicha institución; en noviembre de 1963 fue nombrado Consejero Delegado de la Sección de Cinematografía y Televisión y, en febrero de 1966, Jefe del Departamento de Sinfónicos y Copistería. Véase Pérez Zalduondo, El compositor José Muñoz Molleda, p. 114.

${ }^{61}$ Los restantes manuscritos contienen guiones u orquestaciones de Muñoz Molleda de materiales originales de Mostazo o de autoría compartida con él (Apéndice 1). pliegos de los que resultan treinta y seis páginas - incluyendo la portada - , cada una de ellas con dieciocho pentagramas agrupados por el autor en seis sistemas de tres pentagramas cada uno, salvo algunas páginas en blanco, a modo de separadores de los distintos bloques musicales. La partitura está escrita en forma de guion pianístico con algunas indicaciones relativas a la instrumentación.

El guion consta de once bloques identificados con respecto a los números de escena del guion cinematográfico para el que fueron compuestos. El cotejo de este guion con la película constata la desaparición, en el metraje final, de algo más de la mitad de los 875 compases que conforman la música original de Muñoz Molleda. Resumimos esta situación en la Tabla 1, donde el signo "_-" indica las secciones totalmente eliminadas del montaje final, "(-)" las secciones parcialmente eliminadas y "+" los añadidos no reflejados en el guion.

Esta partitura ofrece valiosísimas pistas acerca de los cambios operados desde la fase de preproducción hasta el montaje del filme y permite, en ocasiones, "reconstruir" algunas escenas presuntamente eliminadas durante este proceso. Así, en el bloque $\mathrm{n}^{\mathrm{o}} 1$-correspondiente a los títulos de crédito (00:00) ${ }^{62}$ y las escenas de apertura del filme (01:54) — , la supresión de las dos primeras secciones en "Andante" y "Allegretto" sugiere la simplificación de una secuencia inicial que pudo haber contrapuesto la paz de las calles de Triana a media mañana ("Andante") con la irrupción de la caballería de los dragones de Alcalá, ("Allegretto"). ${ }^{63}$ De modo similar, la música de ritmo danzable y colorido neocastizo del bloque $n^{\circ} 4$ que acompaña la salida de prisión de Antonio Vargas y su galanteo con las viandantes sevillanas (43:30) permite adivinar, gracias al carácter sombrío y repetitivo del "Adagio" precedente y a la similitud temática del "Allegretto" suprimido con el "Allegro non troppo" posterior, la eliminación de una escena situada en el interior de la prisión en la que el torero habría recibido la noticia de su liberación.

${ }^{62}$ La desaparición del "Tranquilo grandioso" que abre los títulos de crédito en la versión española puede deberse a la eliminación en la edición comercial, por deterioro, de los fotogramas iniciales del filme.

${ }^{63}$ Los títulos de crédito de la versión alemana, recompuestos por Milde-Meissner, arrancan con la estentórea versión de TA en Mi menor correspondiente a la segunda interpolación del bloque $\mathrm{n}^{\circ} 3$; véase el apartado 4.2.3. Siguen los cuatro últimos compases del "Tranquilo grandioso" del bloque $n^{\circ} 1$, que enlazan bruscamente con los toques de fanfarria (en Mi bemol mayor) que trataremos en el apartado 4.2.4 para dar paso a la marcha militar en Sol mayor del bloque $\mathrm{n}^{\mathrm{0}} 6$. 


\begin{tabular}{|c|c|c|}
\hline Título original del bloque & $\begin{array}{c}\text { Secciones (indicación de tempo y número } \\
\text { de compases) }\end{array}$ & $\begin{array}{l}\text { Número de página y } \mathbf{n}^{\circ} \\
\text { de compases por página }\end{array}$ \\
\hline $\begin{array}{l}\text { 1. "Introducción" } \\
\text { "Escena del } 1 \text { al 3" }\end{array}$ & $\begin{array}{l}\text { Tranquilo grandioso (9 cc.). } \\
\text { Allegretto }(25 \mathrm{cc} .) \text {. } \\
\text { Despacio }(1 \mathrm{c} .) \text {. } \\
\text { Andante apasionado }(27 \mathrm{cc} .) \text {. TA [abac] } \\
\text { - Andante }(4 \mathrm{cc} .) \text {. } \\
\text { - Allegretto } 4 \text { cc.). } \\
\text { Andante }(2 \mathrm{cc} .) \text {. } \\
\text { Allegretto }(2 \mathrm{cc} .) \text {. } \\
\text { Allegretto }(7 \mathrm{cc} .) \text {. }\end{array}$ & pp. 2-4 (31/26/24). \\
\hline $\begin{array}{l}\text { 2. "Escena } 37 \text { hasta la canción Triana... } \\
\text { Triana" }\end{array}$ & $\begin{array}{l}+ \text { (introducción) }(8 \mathrm{cc} .) \\
\text { Andante tranquilo }(15 \mathrm{cc} .)\end{array}$ & $\begin{array}{l}\text { p.5 (15) } \\
\text { p.6 en blanco }\end{array}$ \\
\hline 3. "Seguido a la canción Triana... Triana" & $\begin{array}{l}\text { Poco movido ( } 33 \text { cc.). } \\
\text { + (interpolación/nueva) ( } 52 ") \text {. } \\
\text { Moderato ( } 23 \mathrm{cc} .) \text {. } \\
\text { Andante tranquilo ( } 13 \mathrm{cc} .) \text {. TA [a]. } \\
\text { Pesante muy despacio }(4 \mathrm{cc} .) \text {. } \\
\text { + (interpolación/repetición) }(9 \mathrm{cc} .) \text {. } \\
\text { - Allegro (4 cc.). }\end{array}$ & $\begin{array}{l}\text { pp. } 7-9(39 / 24 / 14) \\
\text { p. } 10 \text { en blanco }\end{array}$ \\
\hline $\begin{array}{l}\text { 4. "Escena del } 53 \text { al 57" } \\
\text { "Escena } 58 \text { y } 59 "\end{array}$ & $\begin{array}{l}\text { - Adagio (6 cc.). } \\
\text { - Allegretto (8 cc.). } \\
\text { - Adagio (18 cc.). } \\
\text { Allegro non troppo }(30 \mathrm{cc} .) \text {. } \\
\text { - Más despacio }(11 \mathrm{cc} .) \text {. } \\
\text { (-) Allegro non troppo }(33 \mathrm{cc} .) \text {. }\end{array}$ & $\begin{array}{l}\text { "Escena del } 53 \text { al } 57 " \\
\text { "Escena } 58 \text { y } 59 "\end{array}$ \\
\hline $\begin{array}{l}\text { 5. "Escena 65" } \\
\text { "Escena 66" } \\
\text { "Escena 67" } \\
\text { "Escena 68" } \\
\text { "Escena 69" } \\
\text { "Escena } 70 \text { al 89" }\end{array}$ & $\begin{array}{l}\text { - Lento (17 cc.). } \\
\text { Andante }(51 \mathrm{cc} .) \\
\text { [sin cambio de tempo] (4 cc.) } \\
\text { Poco agitato }(4 \mathrm{cc} .) \text { TA [a] } \\
\text { Tranquilo }(11 \mathrm{cc} .) \text { TA [a] } \\
\text { - Un poco Allegro }(21 \mathrm{cc} .) \\
\text { - Agitato }(32 \mathrm{cc} .) \text { TA [a] } \\
\text { - Andante }(6 \mathrm{cc} .) \\
\text { - Adagio }(6 \mathrm{cc} .) \\
\text { - Adagio }(7 \mathrm{cc} .) \\
\text { - Adagio }(4 \mathrm{cc} .) \\
\text { - Andante movido }(36 \mathrm{cc} .) \\
\text { - Adagio }(8 \mathrm{cc} .) \\
\text { - Andante ritmico }(14 \mathrm{cc} .) \\
\text { - Adagio }(3 \mathrm{cc} .) \\
\text { - Andante ritmico }(4 \mathrm{cc} .) \\
\text { Más movido }(45 \mathrm{cc} .) \\
\text { - Allegro }(12 \mathrm{cc} .)\end{array}$ & $\begin{array}{l}\text { pp. } 15-21 \\
(31 / 42 / 44 / 44 / 43 \\
/ 40 / 41) \\
\text { p. } 22 \text { en blanco }\end{array}$ \\
\hline [1.1] "Tema de amor" & $\begin{array}{l}\text { Despacio ( } 1 \text { c.). } \\
\text { Andante apasionado (27 cc.). TA [abac] }\end{array}$ & $\begin{array}{l}\text { (extraído de } 1 . \\
\text { Introducción, nueva } \\
\text { orquestación) }\end{array}$ \\
\hline 6. "Escena 106. Marcha militar" & $\begin{array}{l}\text { - Marcha militar (en La mayor) (59 cc.) } \\
\text { (-) Marcha militar (en Sol mayor) (59 cc.) } \\
\text { + Fanfarrias militares }\end{array}$ & $\begin{array}{l}\text { pp. 23-24 (47/12) } \\
\text { p. } 25(43-46) \\
\text { p. } 26 \text { en blanco }\end{array}$ \\
\hline [1.2] “Tema de amor” (desarrollo) & $+\mathrm{TA}[\mathrm{a}-\mathrm{b}-]$ & $\begin{array}{l}\text { (inspirado en } 1 \\
\text { Introducción, nueva } \\
\text { composición) }\end{array}$ \\
\hline
\end{tabular}




\begin{tabular}{|c|c|c|}
\hline Título original del bloque & \begin{tabular}{|c|} 
Secciones (indicación de tempo y número \\
de compases)
\end{tabular} & $\begin{array}{l}\text { Número de página y } \mathrm{n}^{0} \\
\text { de compases por página }\end{array}$ \\
\hline 7. "Escena 128. Después del beso" & $\begin{array}{l}\text { - Andante (21 cc.) } \\
\text { Copla. Despacio ("Crucecita de hierro") (12 } \\
\text { cc.) CH }\end{array}$ & p. $27(33)$ \\
\hline 8. "Escena 139 y $140 "$ & $\begin{array}{l}\text { - Allegretto }(20 \text { cc.) } \\
\text { - Andante tranquilo (15 cc.) AV1 }\end{array}$ & pp. 28-29 (29/6) \\
\hline 9. "Escena 160" & - Andante religioso (Armonio) (20 cc.) & pp. $30(20)$ \\
\hline 10. "Escena 154 al 156" & $\begin{array}{l}\text { - Allegro }(24 \text { cc.) } \\
\text { - Allegro moderato }(94 \text { cc.) TA[a], CH } \\
\text { - Despacio }(5 \text { cc.) } \\
\text { - Allegro/1er tempo }(21 \mathrm{cc} .) \\
\end{array}$ & $\begin{array}{l}\text { pp. 31-35 (30/30/30 } \\
/ 30 / 24)\end{array}$ \\
\hline 11. "Escena final" & $\begin{array}{l}\text { Marcha fúnebre (16 cc.) TA [a] } \\
\text { Grandioso (4 cc.) TA [a] }\end{array}$ & p. $36(20)$ \\
\hline
\end{tabular}

Tabla 1. Bloques musicales del manuscrito MMolleda\034, que contiene el guion musical de Carmen, la de Triana.

En otras ocasiones, la eliminación de un bloque musical parece responder a la sustitución por otro tipo de música. Este es el caso del bloque $\mathrm{n}^{\circ} 7$, en el que la guitarra flamenca que escuchamos a lo lejos durante el cortejo de Antonio Vargas a Carmen (1:08:38), ${ }^{64}$ sustituye al "Andante" previsto por Muñoz Molleda antes de la copla "Crucecita de hierro". ${ }^{55}$ Una situación pareja habría tenido lugar con respecto a la desaparición del bloque $\mathrm{n}^{\circ} 8$, el cual, por algunas de sus características musicales —ritmo animado en el "Allegretto", cita de la frase "Era Antonio Vargas Heredia el gitano...", (motivo AV1, procedente de la zambra "Antonio Vargas Heredia") — y su ubicación en el manuscrito, podría corresponder al momento en el que el torero es recibido en la posada a las afueras de Sevilla poco antes de la feria (1:17:30); esta escena emula la entrada de Escamillo acompañado de su tema musical en el acto II de la ópera de Bizet y se sostiene en la película únicamente con los vítores de la multitud. ${ }^{66}$

Frente a la relativa evidencia de los ejemplos anteriores, no siempre es fácil determinar la razón de la omisión de un bloque musical. Así, ante el "Andante religioso" para armonio que constituye el bloque $\mathrm{n}^{\circ} 9$, podemos considerar dos hipótesis, ambas vinculadas con la escena del duelo de Carmen por la muerte de Antonio Vargas

${ }^{64}$ El guitarrista responsable de los toques del filme es el célebre Ramón Montoya, participante en el Concurso de Cante Jondo organizado en Granada por Manuel de Falla en 1922.

${ }^{65}$ Este bloque musical se mantiene en su integridad en la versión alemana de la película.

${ }^{66}$ La versión alemana desestima también el bloque $n^{\circ} 8$, pero reutiliza el bloque $n^{\circ} 4$ para acompañar la llegada del torero a Sevilla.
(1:29:08): o bien el "Andante religioso" fue remplazado por la canción fúnebre "La muerte de Vargas Heredia", o bien fue eliminado de un plan que previera ambos números desde el principio y del que habría sobrevivido únicamente la canción. La improbabilidad de que una escena de duelo tan larga situada poco antes del desenlace haya sido siquiera concebida por un director de cine tan experimentado como Rey, inclina la balanza por la primera opción, lo cual señalaría a "La muerte de Vargas Heredia" (1:29:44) como la última canción en incorporarse al filme. Esta hipótesis cuadra con la singularidad de esta especie de aria operística hecha a medida del momento dramático y que, con su cita de la frase "De Puentegení a Lucena..." (motivo AV2, procedente de la zambra "Antonio Vargas Heredia"), se erige a la vez en el número cantado menos autónomo del filme y en una fragmento de "música pura" destinado a recapitular, en forma de epitafio, uno de los principales temas musicales de la película. ${ }^{67}$

\subsection{Temas y motivos conductores de Carmen, la de Triana}

\subsubsection{El "tema de amor" (TA)}

El tema musical más recurrente en la partitura de Muñoz Molleda es el que hemos denominado "tema de amor" (TA), una extensa y desarrollada melodía provista

67 "La muerte de Vargas Heredia" es, por las razones expuestas, la única canción del filme que no ha pasado a formar parte del "canon" de la copla andaluza y la que menos grabaciones fonográficas ha suscitado (Apéndice 3). 


\section{José Muñoz Molleda: Carmen, la de Triana (extracto)}

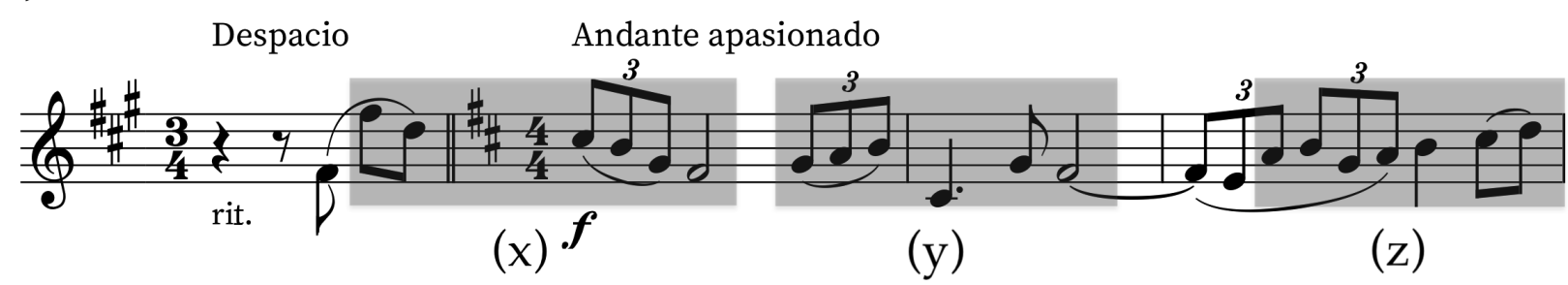

\section{Giacomo Puccini: Crisantemi (extracto)}

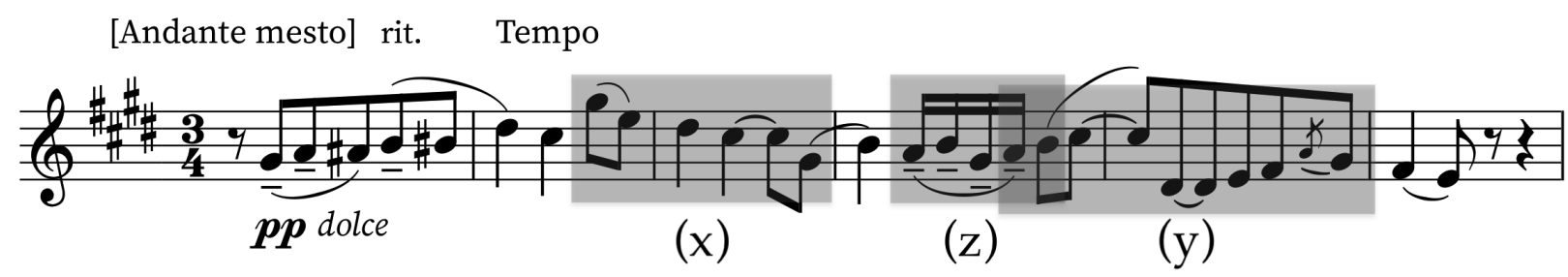

Ejemplo 1. Comparación del inicio del "tema de amor" de Carmen, la de Triana y el inicio del cuarteto de cuerda Crisantemi, de Giacomo Puccini.

de discretos giros andaluces que se inicia con un diseño característico en la obra cinematográfica de este autor. ${ }^{68}$ $\mathrm{Su}$ arranque presenta además similitudes notables con el tema principal del movimiento para cuarteto de cuerda Crisantemi, composición juvenil de Giacomo Puccini que reutilizó posteriormente en Manon Lescaut, ópera que Muñoz Molleda pudo haber conocido durante su estancia romana (Ejemplo 1). ${ }^{69}$

El "tema de amor", de 27 compases de extensión, tiene una estructura [a b a c] en la que [a] (7 cc.) es el tema propiamente dicho, [b] (7 cc.) es un puente contrastante y [c] (6 cc.) una extensión del tema a modo de coda. El tema completo es expuesto dos veces a lo largo del filme: la primera durante los títulos de crédito iniciales (bloque $\mathrm{n}^{\mathrm{o}}$ 1, en Si menor, 00:30) y, la segunda, con una orquestación más ligera en la que el oboe lleva la melodía, en la escena en la que Carmen vela al convaleciente José en la cueva de los contrabandistas (bloque $\left.\mathrm{n}^{\mathrm{o}} 1.1,59: 04\right)$. Este

${ }^{68}$ Se trata del salto ascendente del quinto al tercer grado de la escala — Fa sostenido (en este ejemplo, con octava superior), $\mathrm{Re}$ - y descenso por grados conjuntos hasta la tónica - Do sostenido, $\mathrm{Si}$ - , un patrón característico de la música cinematográfica de Muñoz Molleda identificado y caracterizado por García Soriano, La música en el cine español de la posguerra, p. 634.

${ }^{69}$ La similitud temática de las novelas de Prévost y Merimée podría haber facilitado la asociación entre ambas heroínas y sus respectivos temas musicales. bloque, al igual que el $n^{\circ} 1.2$ (1:02:52), basado también en TA — esta vez, solo las secciones [ab] expandidase igualmente en Si menor, no constan en el manuscrito MMolleda 034 , sino que son añadidos realizados con posterioridad. La disposición simétrica de ambos bloques con respecto a la escena de las alucinaciones castrenses de José (bloque $\mathrm{n}^{\circ} 6$ ), y el ropaje armónico más sombrío del segundo de ellos - en el que el tema [a] es expuesto en forma de un tortuoso canon - contribuyen a señalar el punto de inflexión de los sentimientos del brigadier hacia Carmen, dominados cada vez más por el deseo de redimirse como militar. Aparte de las citas completas de TA, la cabeza del tema [a] es utilizada de forma consistente a modo de leitmotiv a lo largo de toda la película. Ocurre así en los bloques no 3 (la "Noche de amor"), no 5 (la escena de la vieja gitana) y ${ }^{\circ} 10$ (la corrida de toros) y estalla al final del filme (bloque $\mathrm{n}^{\circ} 11$, en Do menor) en la más pura tradición verista.

\subsection{2. "Antonio Vargas" (AV)}

Los restantes motivos musicales recurrentes proceden de la parte diegética de su banda sonora, en concreto, de dos de sus canciones: "Crucecita de hierro" - que trataremos más adelante-, y la zambra "Antonio Vargas Heredia", origen de dos motivos que servirán indistintamente para evocar al torero (17:42). El primero de ellos es la frase que corresponde al texto "Con un clavé grana 


\section{Juan Mostazo: «Antonio Vargas Heredia»}

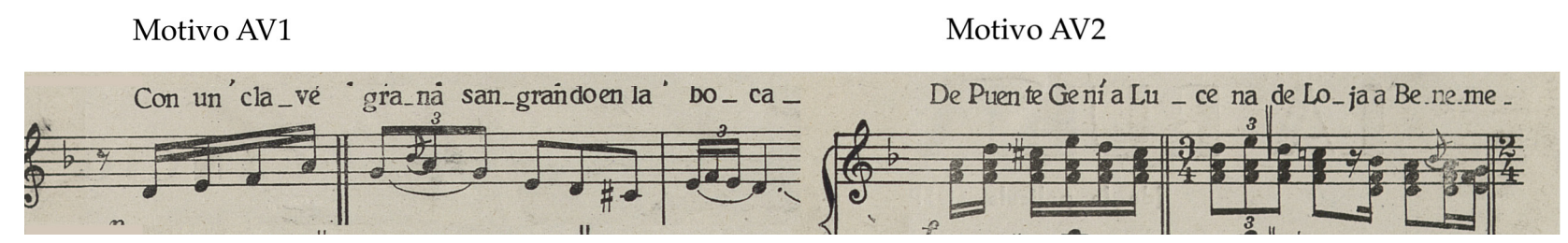

Ejemplo 2. Fragmentos de la zambra "Antonio Vargas Heredia" reutilizados como motivos conductores en varias escenas del filme, extraídos de Juan Mostazo. Antonio Vargas Heredia, canción-zambra del film Carmen, la de Triana (Música Moderna, ca. 1940, Biblioteca Nacional, MP/5901/39).

sangrando en la boca" (AV1) y, el segundo, la que corresponde a "De Puente Gení a Lucena, de Loja a Benamejí" (AV2). Como hemos visto, AV1 reaparece en el bloque $\mathrm{n}^{\circ}$ 8 (la llegada del torero a Sevilla) finalmente suprimido y AV2 es utilizado tanto en la segunda parte del pasodoble homónimo que escuchamos en mitad de la corrida de toros, como en los incisos instrumentales de la oración fúnebre "La muerte de Vargas Heredia", como metonimia de la frase que concluye con "las mositas de Sierra Morena se mueren de pena llorando por ti".

\subsection{3.. La "Noche de amor"}

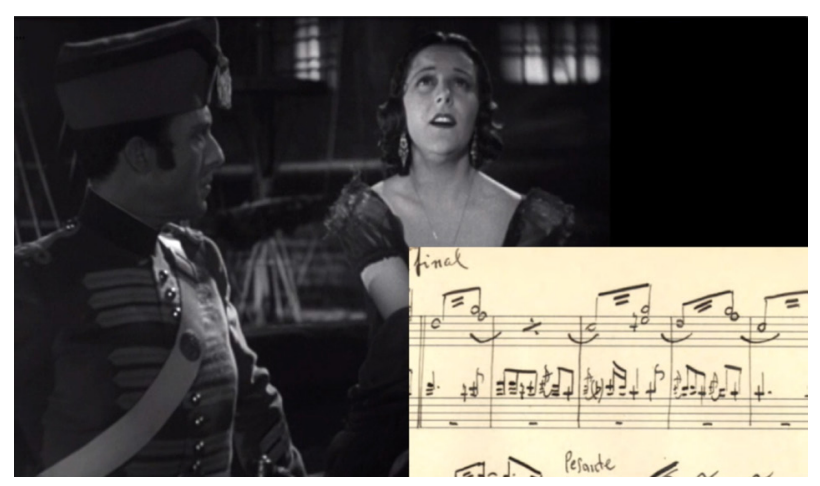

Figura 1. Imagen de la sobreimposición de la partitura de Muñoz Molleda en la escena "Noche de amor".

El tema de amor (TA) juega un importante papel en la secuencia musical de más de diez minutos de duración a la que nos referiremos como "Noche de amor", la única del guion musical que ganó compases en lugar de perderlos. Esta secuencia enlaza sin solución de continuidad el bloque $\mathrm{n}^{\circ} 2$, la canción "Triana, Triana" y el bloque $\mathrm{n}^{\circ} 3$. La mano orquestadora de Muñoz Molleda en el cantable de Mostazo asegura la unidad del conjunto y eleva la canción a un registro inusualmente serio, patente desde la introducción con el solo de oboe sobre un trémolo agudo de violines y la respuesta de la cuerda en el registro grave, de inconfundible concepción sinfónica. ${ }^{70}$

La versión cinematográfica del bloque $\mathrm{n}^{\circ} 2$ (25:56) incluye una introducción de ocho compases no prevista en el guion musical. La lírica melodía que lo preside, encomendada en el manuscrito al violín, aparece en el filme distribuida en tres segmentos, a cargo del oboe, los violines y el clarinete, respectivamente. El acorde final (Sol mayor) permite un enlace sin costuras con el trémolo de violines en Do mayor que da inicio a la canción "Triana, Triana", en la que Carmen se recrea en la belleza de Sevilla frente a los reflejos nocturnos del Guadalquivir (27:41).

Al término del cantable, continúa el bloque $n^{0} 3$ (31:04), cuya versión definitiva acumula dos interpolaciones y un breve corte; véase Tabla 2 . La primera de ellas (32:23), cincuenta y dos segundos de nueva composición situados entre el "Poco movido" y el "Moderato", acompaña el momento en el que la pareja entra a oscuras en la casa de Carmen y ésta enciende las velas. Consta de un tenue pedal agudo en Si teñido con sombríos acordes y el desarrollo, en un contexto tonal inestable, del motivo inicial de

${ }^{70}$ Las versiones de las canciones recogidas en el filme están generalmente abreviadas y cuentan con diversos retoques de orquestación. En el caso de las "Carceleras del Puerto" y "Antonio Vargas Heredia", son reseñables los efectos de sfumatura, o suave transición del acompañamiento diegético al extradiegético, al inicio de cada canción. Por su parte, "Los piconeros" incluye estribillos corales entonados por la clientela del café del Mulero. En contraste con estas adaptaciones, dictadas por exigencias dramáticas, las dirigidas al mercado fonográfico (dirigidas igualmente por Milde-Meissner, Apéndice 3) pueden considerarse versiones "oficiales". 


\begin{tabular}{|c|c|}
\hline Bloque no 3. Guion musical & Montaje final \\
\hline \multirow[t]{2}{*}{ 1. "Poco movido" (33 cc.) } & 1. "Poco movido" (33 cc.) \\
\hline & $\begin{array}{l}\text { + Interpolación 1: } \\
\text { + Pedal Si de dominante } \\
+ \text { TA (desarrollo) }\end{array}$ \\
\hline $\begin{array}{l}\text { 2. "Moderato" }(18 \mathrm{cc} .) \\
\text { "poco a poco agitato" }(5 \mathrm{cc} .) \\
\text { [RETRETA] }\end{array}$ & $\begin{array}{l}\text { 2. "Moderato" (18 cc.) } \\
\text { "poco a poco agitato" (5 cc.) }\end{array}$ \\
\hline 3. "Andante tranquilo" (13 cc.), TA en Mi menor & 3. "Andante tranquilo" (13 cc.), TA ( $p)$ \\
\hline \multirow[t]{2}{*}{ 4. "Pesante" (4 cc.) } & 4. "Pesante" (4 cc.) \\
\hline & $\begin{array}{l}\text { Interpolación } 2 \text { : } \\
\text { 2. "poco a poco agitato" ( } 5 \text { cc. }) \\
\text { [RETRETA] } \\
\text { 3. "Andante tranquilo" ( } 4 \text { cc. }), \text { TA }(f f)\end{array}$ \\
\hline 5. "Allegro" (4 cc.) & [suprimido] \\
\hline Siguiente escena: tambores militares & Siguiente escena: tambores militares \\
\hline
\end{tabular}

Tabla 2. Comparación del guion musical de José Muñoz Molleda para el bloque $\mathrm{n}^{\mathrm{o}} 3$ de Carmen, la de Triana con la versión correspondiente al montaje final.

TA. ${ }^{71}$ La segunda interpolación (35:54), situada al final de la secuencia, consiste en la repetición de dos fragmentos previos: el "poco a poco agitato" situado al final del "Moderato" y el inicio del "Andante tranquilo" (TA) en una nueva y estentórea orquestación. Estas interpolaciones tienen como resultado que, en la versión final de esta escena, TA aparezca parcialmente hasta en tres ocasiones - en lugar de una sola- en una progresión crecientemente asertiva. El toque de corneta - ausente en el guion musical — que recuerda a José sus obligaciones castrenses pudo estar previsto desde el principio en la cesura situada entre el "Moderato" y el "Andante tranquilo", tal como ocurre en el montaje final. De este modo, la versión definitiva de la partitura habría reducido el tiempo transcurrido entre la retreta y el final de la escena en un lapso estimable en unos cincuenta segundos.

El efecto combinado de estas alteraciones sugiere, con respecto a la primera interpolación y la exposición en progresión de TA, una realización más pausada de la escena en la casa de Carmen, probablemente en aras de una mayor veracidad psicológica. Por su parte, la reducción del intervalo

${ }^{71}$ Esta interpolación figura por segunda vez en la versión alemana del filme, junto con una reelaboración de otros materiales pertenecientes al bloque $\mathrm{n}^{\circ} 3$, en la breve secuencia musical que acompaña la visita furtiva de José, ya convertido en bandolero, a Carmen. En la versión española, la escena está acompañada por el sonido lejano de la guitarra flamenca de Ramón Montoya, proveniente de la taberna de Zahara. entre la retreta y el final de la secuencia habría contribuido a reforzar de forma subliminal el nexo causal entre la acción irresponsable de José y su castigo. Este efecto se debe a que la "Noche de amor" es bruscamente truncada por los tambores militares que acompañarán la degradación del brigadier en la escena siguiente, dotando al final de esta secuencia de amores prohibidos y deberes desatendidos de una cualidad interruptus con lejanas resonancias tristanescas. ${ }^{72}$

\subsubsection{Los toques militares y la redención del brigadier}

El toque de retreta de la "Noche de amor" (36:04) es solo uno de los muchos toques militares - cornetas a solo y fanfarrias imperiales - que no figuran en el guion musical y fueron añadidos con posterioridad; véase Tabla 3. La similitud de los toques militares del filme con respecto a los oficiales es más bien anecdótica ${ }^{73} \mathrm{y}$, además, en los casos en los

${ }^{72}$ La versión alemana del filme resuelve de manera más convencional este cambio de secuencia: el tema de amor concluye con un luminoso acorde de Mi mayor que se apaga lentamente con el beso de amor a la vez que el fundido en negro prepara la entrada de los tambores militares y la degradación de José.

${ }^{73}$ Hemos cotejado los toques del filme con los recogidos en el Reglamento de Empleo. Toques Militares, RE7-001, aprobado en la Resolución 552/18147/05 de la Dirección de Doctrina, Orgánica y Materiales, dependiente del Mando de Adiestramiento y Doctrina del Ejército de Tierra español, 2005. Este reglamento incluye toques cuyos orígenes se remontan a los siglos XVIII y XIX. 


\section{Paso ordinario del Ejército de Tierra (RE7-001)}

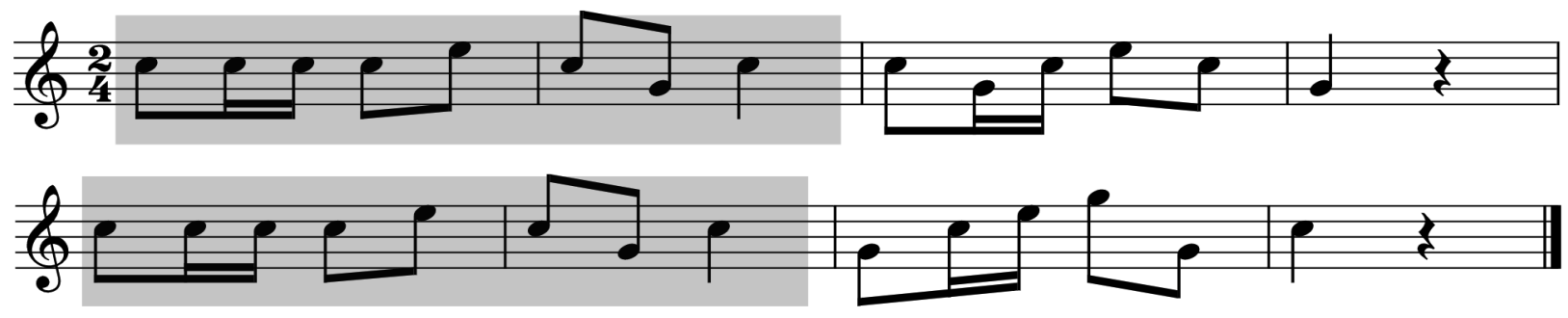

\section{Carmen, la de Triana: toque de retreta}

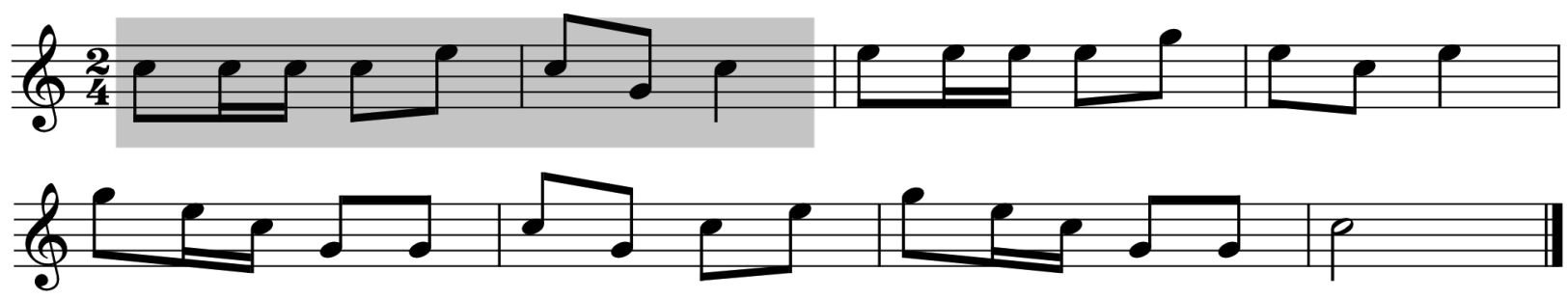

Ejemplo 3. Comparación entre el toque de paso ordinario del Ejército del Aire español (RE7—001, pp. 113 y 225) y el toque de retreta utilizado en Carmen, la de Triana (36:04 y 1:02:18), en una transcripción propia.

que unos y otros guardan algún parecido musical, no existe correspondencia respecto con su función. Así, por ejemplo, la retreta del filme tiene una frase en común con el toque militar correspondiente al paso ordinario; véase Ejemplo 3.

El toque de corneta que puntúa la entrada de los dragones al inicio del filme (01:54) es otro añadido. Su inusual progresión melódica y su perfecto encaje armónico con los compases finales del bloque $\mathrm{n}^{\circ} 1$, a los que se superpone, revelan su composición ex profeso; véanse Figura 2 y Ejemplo 4.

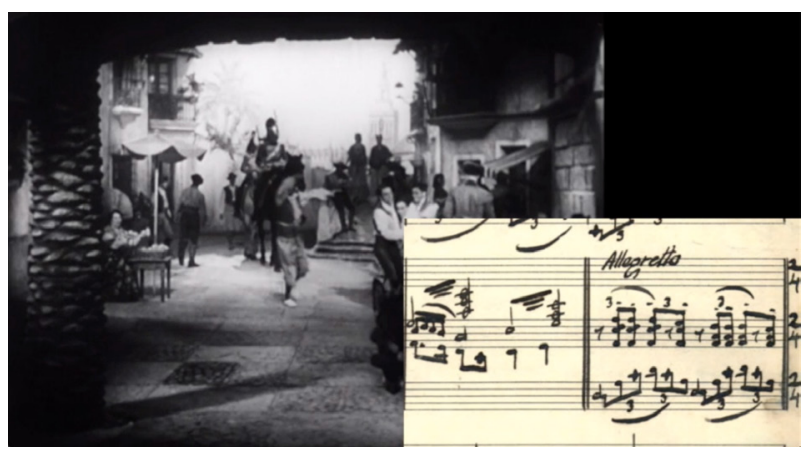

Figura 2. Imagen de la sobreimposición de la partitura de Muñoz Molleda en una escena con el toque de corneta.
En total, la inserción de toques militares se produce en siete ocasiones distintas y cubre todos los niveles narrativos: el diegético (retreta durante la "Noche de amor", la degradación de José y retirada durante la emboscada), el extradiegético (escena de la vieja gitana y alucinaciones de José) y seudodiegético (el resto). ${ }^{74}$ La más notable de ellas es la escena de las alucinaciones de José (1:01:18). De acuerdo con los materiales previstos por Muñoz Molleda, este episodio debía haber sido acompañado mediante una simple marcha militar de carácter más zarzuelístico que propiamente castrense (bloque $\left.n^{0} 6\right) .{ }^{75}$ En su lugar, el filme utiliza un audaz y

${ }^{74}$ Con este último nivel nos referimos a los efectos musicales que - como la guitarra flamenca en los cafés y los pasodobles en el ruedo - no son directamente visibles, pero asumimos, por el contexto, que proceden de la escena y son audibles por los personajes. Los toques de corneta que, como el superpuesto al bloque $\mathrm{n}^{\circ} 1$, acompañan las apariciones de la caballería de dragones, pueden asimilarse a este nivel.

75 Esta marcha aparece en el manuscrito en dos versiones distintas: una en La mayor y otra en Sol mayor. Como hemos visto en la nota 63 , la versión alemana hace uso de esta marcha 

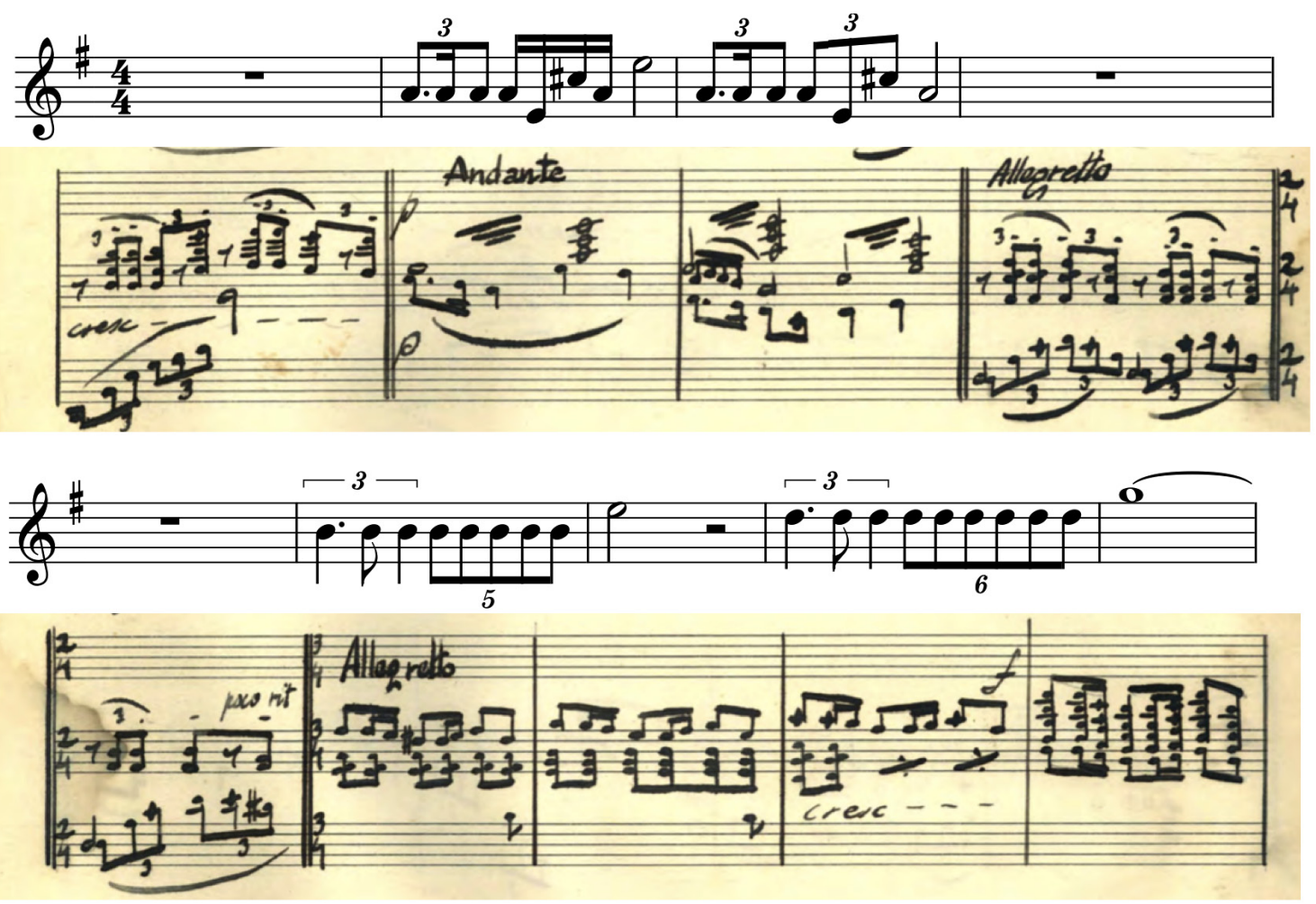

Ejemplo 4. "Escenas 1-3", cc. 8-19 (MMolleda\034, p. 4, más transcripción propia del toque de corneta). El primer toque de corneta, de dos compases de duración y en La mayor, dobla el trémolo del acorde de La (menor) de la cuerda, mientras el segundo, coincidente con los 4 primeros compases del último "Allegretto", dobla las fundamentales de los acordes correspondientes a cada uno de los compases con los que se superpone.

efectivo collage sonoro que combina un breve fragmento de esta marcha, en Sol mayor, con una fanfarria (Figura 3) de nueva composición expuesta en las tonalidades de Mi bemol y Si mayor ${ }^{76}$ y la retreta de la "Noche de amor", esta vez en Sol mayor. La cita de la retreta constituye una referencia al momento en el que José incumplió su deber de soldado, mientras que la contraposición de estas tres regiones tonales a distancia de tercera mayor - Mi bemol, Si y Sol-, dota a la secuencia del efecto alucinatorio deseado. ${ }^{77}$

(versión en Sol mayor) de forma extensiva en los títulos de crédito y las escenas iniciales de la película.

76 Se trata de la misma fanfarria que la versión alemana utiliza en los títulos de crédito.

77 Los círculos de terceras - mayores y menores - fueron una de las señas de identidad del último Rimski-Kórsakov. Respighi — como discípulo del ruso y profesor de Muñoz Molleda durante su estancia romana- pudo haber jugado algún papel en

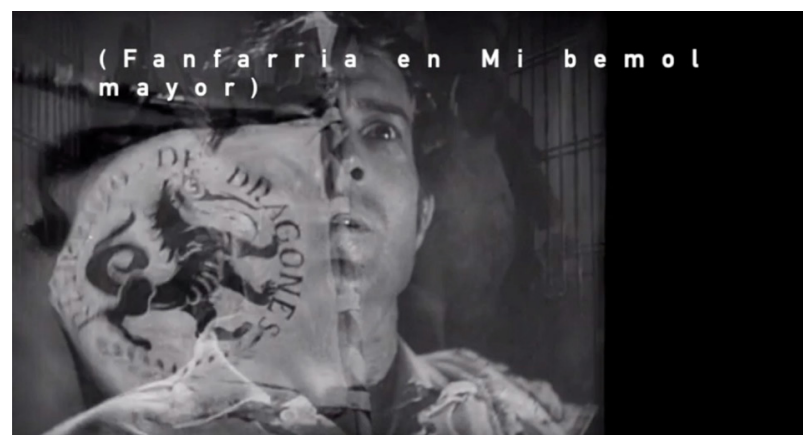

Figura 3. Imagen de la escena de la alucinación de José en la que se escucha la fanfarria en Mi bemol mayor.

la transferencia de estos formularismos armónicos, asociados por lo general a situaciones de magia o irrealidad. 

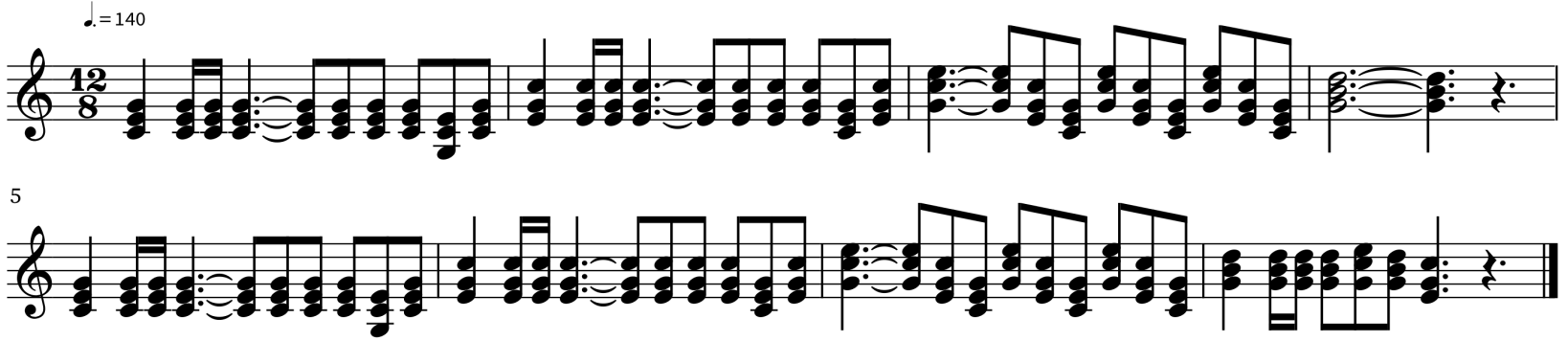

Ejemplo 5. Transcripción propia (en Do mayor) de la fanfarria de dragones utilizada en la versión final del bloque ${ }^{\circ} 6$.

\begin{tabular}{|l|l|l|l|}
\hline \multicolumn{1}{|c|}{ Minutaje } & \multicolumn{1}{c|}{ Situación } & \multicolumn{1}{c|}{ Bloque } & \multicolumn{1}{c|}{ Similitud/nivel narr. } \\
\hline $01: 54$ & Caballería por las calles de Sevilla & $\mathrm{N}^{\mathrm{o}} 1$ & $\approx$ llamada a oficiales (SD) \\
\hline $36: 04$ & Toque de retreta (en La) & $\mathrm{N}^{\mathrm{o}} 3$ & $\approx$ paso ordinario (D) \\
\hline $36: 36$ & Degradación de José & - & Redoble de tambores (D) \\
\hline $54: 36$ & $\begin{array}{l}\text { Evocación de José en la escena de la vieja } \\
\text { gitana }\end{array}$ & $\mathrm{N}^{\mathrm{o}} 5$ & $\approx$ pelotón/misa (ED) \\
\hline $\begin{array}{l}1: 01: 40 \\
1: 01: 54\end{array}$ & Alucinaciones castrenses de José & $\mathrm{N}^{\mathrm{o}} 6$ & $\begin{array}{l}\text { Fanfarrias en Mi b (ED) } \\
\text { Fanfarrias en Si } \\
\text { ₹ paso ordinario }\end{array}$ \\
\hline $1: 02: 16$ & Toque de retreta (en Sol) & - & $\approx$ carga en línea (SD) \\
\hline $1: 35: 30$ & Caballería por las calles de Sevilla & $\begin{array}{l}\approx \text { llamada a banda/ } \\
\text { variación (D) }\end{array}$ \\
\hline
\end{tabular}

Tabla 3. Toques de corneta, fanfarrias militares y redobles de tambores incorporados a la partitura definitiva de Carmen, la de Triana. La cuarta columna incluye los toques militares auténticos incluidos en el reglamento de toque militares RE7-001 que presentan mayor similitud y el nivel narrativo en el que se sitúa el efecto sonoro: diegético (D), extradiegético (ED) y seudodiegético (SD).

La drástica mutación del bloque $\mathrm{n}^{\mathrm{0}} 6$ que acabamos de describir y, en general, la proliferación de toques militares en la partitura definitiva de esta película, opera en un sentido muy nítido: el refuerzo de los valores castrenses de la versión de Rey, en una reinterpretación del mito de Carmen que coloca al brigadier José como verdadero protagonista del filme y a la fidelidad al ejército como su conflicto central, de acuerdo con valores directamente inspirados en el alzamiento franquista. ${ }^{78} \mathrm{La}$ incorporación a este collage del toque de retreta convierte así a este en la señal musical que puntúa — correlacionándolos- dos momentos clave en la trayectoria vital del protagonista: su caída en desgracia y su propósito de enmienda. ${ }^{79}$

78 Company, "La cruzada del brigadier", pp. 14-19.

${ }^{79} \mathrm{La}$ versión alemana convierte la marcha original de Muñoz Molleda - en alternancia con la fanfarria - en protagonista musical de los títulos de crédito (reescritos por MildeMeissner), extendiendo su uso hasta la entrada de la protago-

\subsubsection{La vieja gitana y la fantasía expresionista}

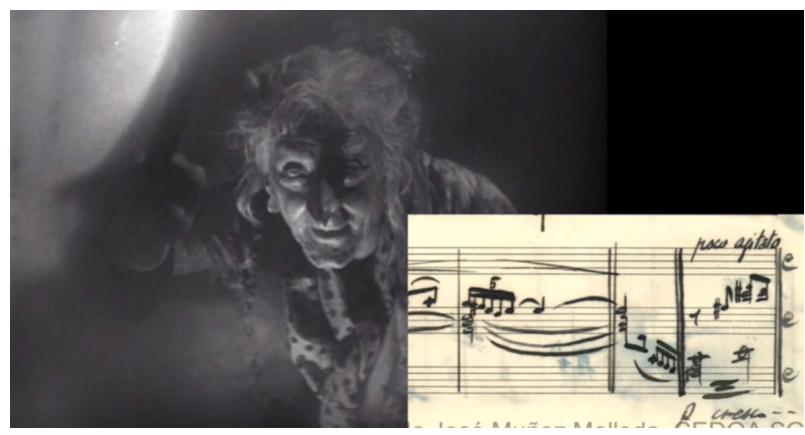

Figura 4. Imagen de la sobreimposición de la partitura de Muñoz Molleda en la escena de la vieja gitana.

nista. Esta algarabía castrense-zarzuelera juega en contra de la gravedad de las advertencias que el comandante Ramírez dirige al recién llegado brigadier José. 

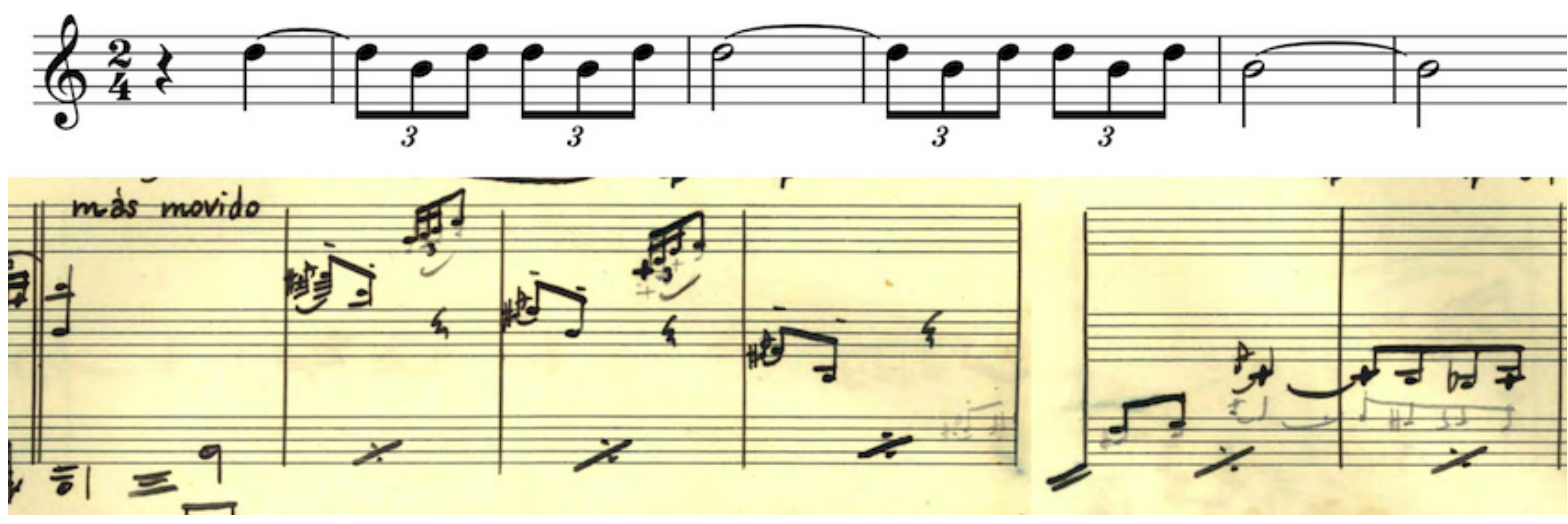

Ejemplo 6. Toque de corneta superpuesto a los seis compases iniciales de la sección "Más movido" del bloque $n^{\circ} 5$ (“Escena 70 al 89”, cc. 89-94, MMolleda\034, p. 20).

Con siete páginas — de un total de treinta con música-, y situado en pleno nudo del drama, este ambicioso bloque $\mathrm{n}^{\mathrm{0}} 5$ (53:12) habría sido unos de los más reseñables de la partitura si no fuera por los severísimos cortes sufridos en la versión definitiva, que retiene solo 102 de los 289 compases previstos en el guion de Muñoz Molleda. ${ }^{80}$

La primera mitad del bloque está plagada de ominosas mixturas ("Lento") que habrían acompañado el penoso camino de Carmen hasta la cueva de la vieja gitana en una escena finalmente descartada. ${ }^{81}$ La supresión de los 141 compases que preceden la indicación "Más movido" supone con toda certeza el corte más doloroso en términos musicales, pues estos compases constituyen la médula de una ambiciosa fantasía sonora y visual en torno a la escena de la vieja gitana.$^{82} \mathrm{La}$ escena quedó finalmente reducida a su mínima expresión, en la que las superposiciones de planos de la muerte anunciada de José, el gato negro, los gestos de espanto de Carmen y el agua hirviente en el que la vieja gitana proyecta sus visiones se reflejan en una poción musical de escalofriantes motivos cromáticos evocadores de las artes mágicas, retazos suplicantes de TA y siniestras armonías disminuidas y aumentadas en una especie

${ }^{80}$ Subsiste casi toda la música correspondiente a las escenas 66 y 67 (el "Andante" sufre un corte en cc. 15-32). Desaparecen los 141 compases que abarcan desde el "Un poco Allegro" de la escena 68 hasta el último "Andante ritmico" (sic.). En la sección "Más movido" se repiten los cc. 9-16 y se sustituyen los cc. 37-45 por 6 nuevos compases de carácter conclusivo. También desaparece el "Allegro" final; véase Tabla 1.

81 Véase Apéndice 2.2.

${ }^{82}$ Sánchez Vidal, El cine de Florián Rey, p. 235: “... una secuencia que es puro expresionismo germánico". de crescendo de horror; véase Apéndice 2.6. A los cortes operados en el guion se suma el añadido de un toque de corneta (Ejemplo 6) que alude de nuevo a José (54:36).

Los cortes efectuados en este bloque podrían explicarse bien por la necesidad de acortar metraje, bien por la falta de recursos fílmicos de Rey (o actorales por parte de Imperio Argentina, visiblemente superada por las exigencias dramáticas) para sostener visualmente una escena tan ambiciosa desde el punto de vista artístico como escasa de soporte narrativo. Sea como fuere, tanto los cortes como el toque de corneta habrían tenido como resultado una nueva pérdida de protagonismo de Carmen, al operar un importante cambio de perspectiva: si el fondo orquestal "expresionista" subordinaba la visión de la muerte de José a su impacto en el estado de ánimo de la gitana, el toque de corneta sitúa al brigadier, una vez más, en primer plano, identificándolo como la víctima de los imprudentes amoríos de la joven.

\subsubsection{La corrida de toros y el gran Finale descartado}

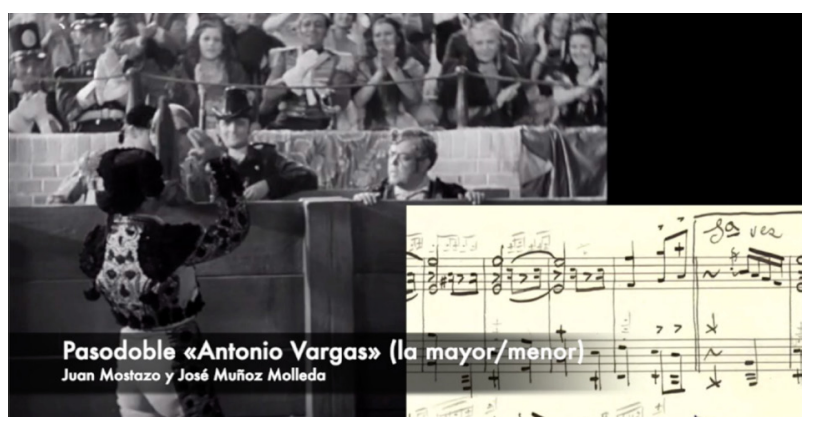

Figura 5. Imagen de la sobreimposición de la partitura del pasodoble "Antonio Vargas" de Juan Mostazo y José Muñoz Molleda en la escena de la corrida de toros. 

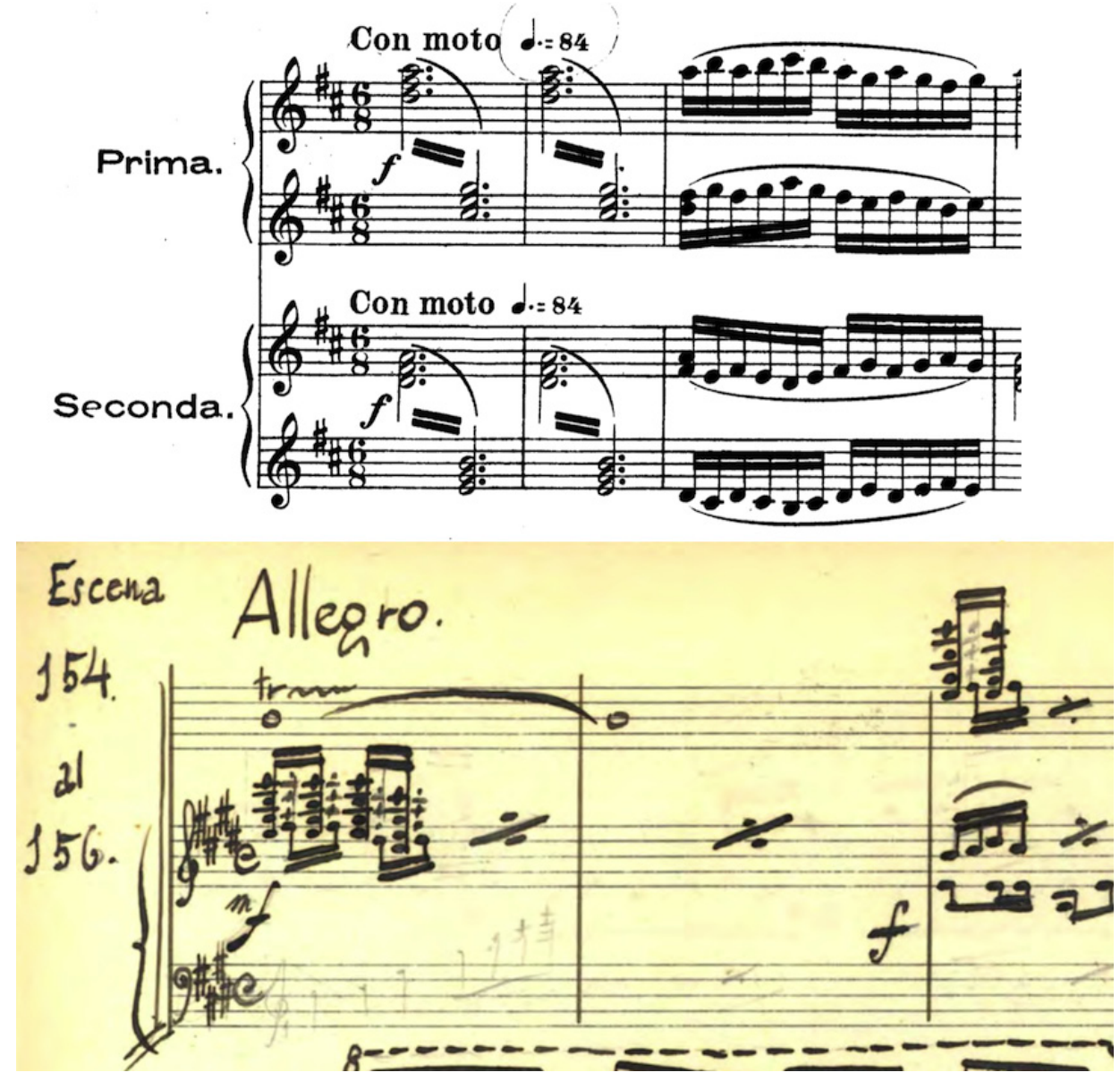

Ejemplo 7. En la parte superior, los compases iniciales del Cuadro IV de Petrushka de Ígor Stravinski, versión para piano a cuatro manos del autor (Berlín: Editions Russes de Musique, 1912), p. 55. En la parte inferior, "Escena 154 al 156", cc. 1-2 (MMolleda\034, p. 31).

Frente al collage en que se convirtió finalmente el bloque $\mathrm{n}^{\circ} 6$ (alucinaciones de José) y el carácter episódico del bloque $n^{\circ} 5$ (escena de la vieja gitana), el bloque $n^{\circ}$ 10 estaba destinado a ser un gran Finale caracterizado por una notable autonomía musical y una equilibrada construcción formal. Su duración estimada (unos 5 minutos), su carácter festivo y con ritmo de pasodoble - en compás de 3/4-y su ubicación en el manuscrito (inmediatamente antes del "Andante religioso" que habría acompañado la muerte del torero), apuntan de forma inequívoca a que este bloque fue concebido para la corrida de toros (1:22:10). El montaje final, sin embargo, prescindió totalmente de esta música y utilizó, con carácter de ambientación, dos pasodobles de nueva composición: "Antonio Vargas Heredia" (MMolleda\037) y "Toros en Jerez", ambos acreditados con doble autoría a Juan Mostazo y Muñoz Molleda (Figura 5). ${ }^{83}$

El bloque en cuestión, con estructura A B C A', arranca con una bulliciosa introducción (A) en Mi mayor en la que es reconocible la influencia del ballet $\mathrm{Pe}$ trushka; véase Ejemplo 7. ${ }^{84}$ Le sigue un lírico pasaje en 3/4 en "Allegro moderato" (B) que, tras realizar una elegante modulación a Sol menor, adquiere ritmo y cuerpo

${ }^{83}$ El pasodoble "Torres de Jerez" ha sido identificado a través del registro fonográfico incluido en el Apéndice 3.24.

${ }^{84}$ Se trata del inicio del cuadro IV de esta partitura stravinskiana que representa el bullicio en una plaza de San Petersburgo durante la festividad del carnaval. 


\begin{tabular}{|c|c|c|c|}
\hline Sección musical & Duración estimada & Secuencia en el ruedo & Duración \\
\hline $\begin{array}{l}\text { A.- Allegro (cc. 1-24). Bullicio } \\
\text { "petrushkiano". }\end{array}$ & $\begin{array}{l}\text { tempo } 110 \mathrm{ppm} \\
\approx 58 \mathrm{~s}\end{array}$ & Paseíllo en la plaza de toros & $46 \mathrm{~s}$. \\
\hline $\begin{array}{l}\text { B.- Allegro moderato (cc. } 25-74) \text {. } \\
\text { Pasodoble en compás ternario. }\end{array}$ & $\begin{array}{l}\text { Tempo } 100 \mathrm{ppm} \\
\quad \approx 1 \mathrm{~m} .30 \mathrm{~s} \text {. }\end{array}$ & $\begin{array}{l}\text { Salida del morlaco, lances de capote } \\
\text { de Antonio Vargas }\end{array}$ & $1 \mathrm{~m} .39 \mathrm{~s}$. \\
\hline $\begin{array}{l}\text { El "tema de amor" se introduce en el } \\
\text { pasodoble (cc. } 75-96)\end{array}$ & $\begin{array}{l}\text { tempo } 100 \mathrm{ppm} \\
\quad \approx 1 \mathrm{~m} .6 \mathrm{~s} .\end{array}$ & $\begin{array}{l}\text { José observa de lejos a Carmen, } \\
\text { diálogo entre Antonio Vargas y } \\
\text { Carmen }\end{array}$ & $1 \mathrm{~m} .7 \mathrm{~s}$. \\
\hline $\begin{array}{l}\text { C.- "Crucecita de hierro" (cantado) } \\
\text { (cc. 97-112) }\end{array}$ & $\approx 32 \mathrm{~s}$ & Brindis de Antonio Vargas & $9 \mathrm{~s}$. \\
\hline $\begin{array}{l}\text { "Crucecita de hierro" en la orquesta y } \\
\text { transición (cc. 113-123) }\end{array}$ & $\approx 22 \mathrm{~s}$ & \multirow[b]{2}{*}{$\begin{array}{l}\text { Se reanuda la corrida, hasta el } \\
\text { momento de la cornada }\end{array}$} & \multirow[t]{2}{*}{$1 \mathrm{~m} .51 \mathrm{~s}$} \\
\hline $\begin{array}{l}\text { A'.- Recapitulación (cc. 124-144). } \\
\text { Bullicio "petrushkiano". }\end{array}$ & $\begin{array}{l}\text { tempo } 110 \mathrm{ppm} \\
\quad \approx 50 \mathrm{~s} .\end{array}$ & & \\
\hline TOTAL & $\approx 5 \mathrm{~m} .18 \mathrm{~s}$. & & $5 \mathrm{~m} .30 \mathrm{~s}$. \\
\hline
\end{tabular}

Tabla 4. Comparación entre las duraciones estimadas de las secciones del bloque $\mathrm{n}^{\mathrm{o}} 10$ y la secuencia en el ruedo.

de pasodoble sin abandonar el compás ternario. El motivo inicial del "tema de amor", introducido subrepticiamente poco antes del final de B, cobra protagonismo mediante un breve desarrollo que conduce a la sección C, una enfática cita de la melodía "Crucecita de hierro" $(\mathrm{CH})$ en registro tenor. Tras una breve transición, sigue la recapitulación de la introducción (A').

Una comparación más detallada entre el guion de Muñoz Molleda y el montaje de la secuencia de la corrida de toros (Tabla 4) muestra una sutil concordancia entre ambas: el Allegro petrushkiano (A) coincidiría con las vistas generales de la plaza y el paseíllo (1:22:10), la salida del morlaco daría inicio a la sección B (1:22:56) y el ritmo de pasodoble ternario se consolidaría con los primeros lances de capote de Antonio Vargas (1:23:10). Las primeras referencias musicales al "tema de amor" habrían coincidido con el travelling con el que descubrimos a José entre el público (1:24:35), y ganarían intensidad mientras el brigadier observa el diálogo entre Carmen y el torero. El final de esta sección y la cita de "Crucecita de hierro" coincidiría con el momento en el que el matador se dispone a brindar el toro a la gitana (1:25:42), mientras la recapitulación del Allegro petrushkiano tras la dramática cogida en el ruedo de Vargas Heredia lo haría con la reanudación de la fiesta en la plaza. ${ }^{85}$

${ }^{85}$ En la versión definitiva de Rey, tampoco la cogida del torero interrumpe la celebración de la corrida, que se reanuda a
El Finale proyectado por Muñoz Molleda sugiere, mediante las nada inocentes incorporaciones de las citas del "tema de amor" y de la copla "Crucecita de hierro" (C) - alusiones a los celos de José y al rechazo de Carmen a las pretensiones amatorias del torero, respectivamente-, una solución más enfática que la finalmente adoptada para esta fundamental secuencia. Este planteamiento habría magnificado el rol de la gitana como vértice del fatal triángulo amoroso. En particular, la indicación "cantando" que acompaña el inicio de "Crucecita de hierro" en la partitura - la única de este tipo en todo el guion- y su ubicación en el registro violonchelístico (Ejemplo 8) acerca esta cita a las que encontramos en la ópera de Bizet referidas al "tema del destino", aunque también podría referirse a que la copla debiera ser, efectivamente, cantada. Un cruel guiño - por lo inadecuado del momento escogido - que, sumado a la alusión musical a los celos del militar, habría evidenciado a la gitana como femme fatal y origen de la desgracia que acaecerá unos instantes después, incidiendo en un planteamiento sin duda contrario a las intenciones de Rey, como pronto veremos. los sones del pasodoble "Toros en Jerez" mientras el matador es trasladado a la enfermería. 


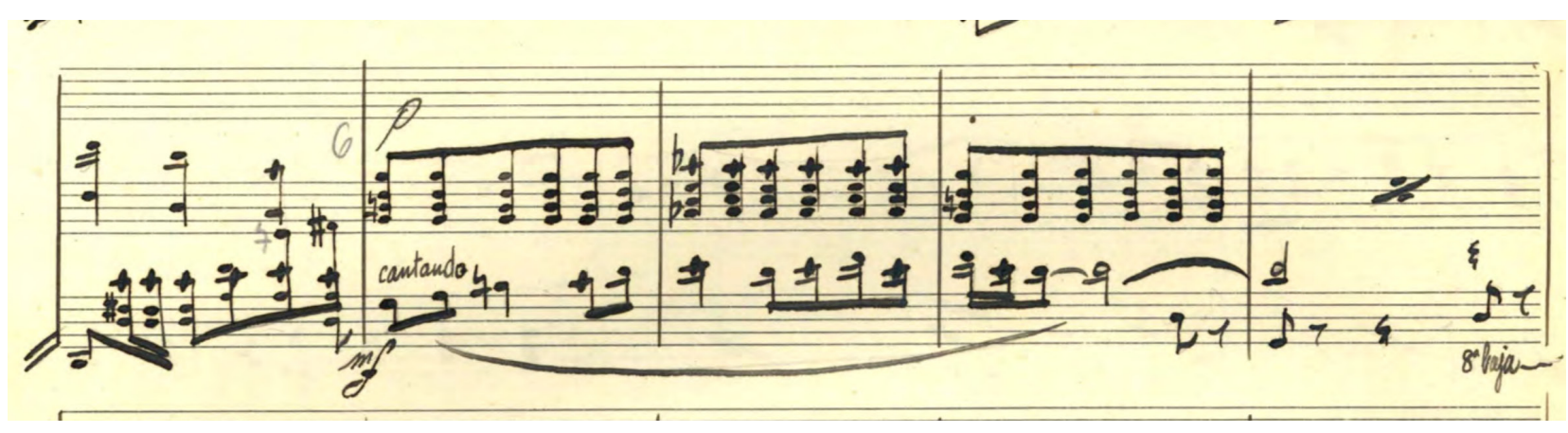

Ejemplo 8. Cita de la canción "Crucecita de hierro" en el bloque no 5 ("Escena 154 al 156", cc. 96-100, MMolleda $\backslash 034$, p. 34). Nótese la expresión "cantando".

\subsubsection{La canción "Crucecita de hierro" (CH) y el afán sinfónico}

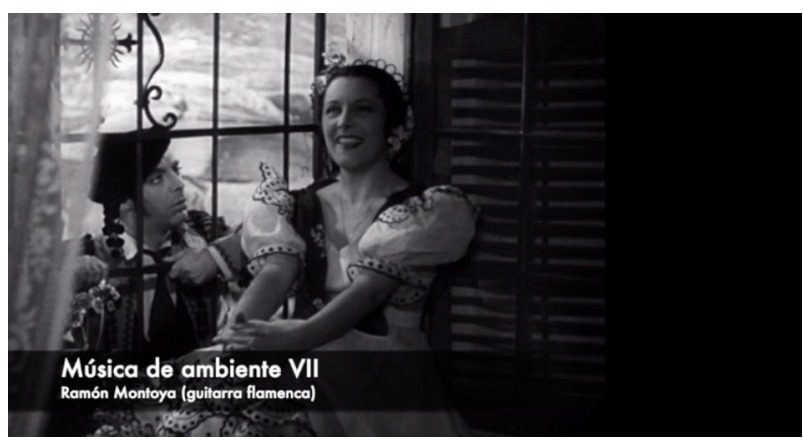

Figura 6. Imagen de la escena de la canción "Crucecita de hierro".

La sustitución del bloque $\mathrm{n}^{\mathrm{0}} 10$ por los pasodobles tuvo como efecto colateral una sensible rebaja de las pretensiones "operísticas" de la secuencia taurina concebida por Muñoz Molleda y la pérdida de la condición de leitmotiv de la copla "Crucecita de hierro" $(\mathrm{CH})$. Este breve cantable encontró, sin embargo, una segunda vida en el medio impreso y fonográfico gracias al aval artístico de Imperio Argentina (véase Apéndice 3.13) en una llamativa operación de merchandising destinada quizá a completar, en concepto de derechos de autor, los honorarios de Muñoz Molleda. ${ }^{86}$ Se trata de la canción titulada "Cru-

${ }^{86}$ La cuantía de estos ingresos pudo no ser despreciable. Téngase en cuenta que, gracias a las canciones compuestas para las películas de Imperio Argentina y Estrellita Castro, Juan Mostazo llegó a ser, una vez finalizada la guerra y a título póstumo, el compositor con mayores ingresos por derechos de autor cecita de hierro", que incluye como sección principal una versión cantada de TA (con letra de Florián Rey), utilizada para enmarcar la copla que da nombre a la canción, según la estructura ternaria TA CH TA.

El registro "lírico" de la orquestación de la canción -así como la interpretación de Imperio Argentinaapunta una vez más a la dimensión de Muñoz Molleda como compositor de música "seria", una faceta que resulta reconocible también en el plan global de la partitura, como ya henos visto con: la integración de la canción "Triana, Triana" en el lírico Adagio de casi doce minutos de duración que hemos denominado "Noche de amor", el desarrollo motívico de TA, la variedad de procedimientos técnicos y estilísticos desplegados a lo largo de la partitura, el carácter de aria de la "Muerte de Vargas Heredia" y el tour de force sinfónico con el que el compositor pretendió culminar, a modo de gran Finale, la secuencia en la plaza de toros.

El carácter cíclico de los principales temas musicales de la película - en algún caso, frustrada por los cortes aplicados a la partitura - es extensivo a algunos materiales diegéticos, como la canción "Los piconeros" que es interpretada por segunda vez con un simple acompañamiento de guitarra en la taberna de Zahara hasta que, en un alarde de anclaje realista, Carmen interrumpe el canto, presa de la inquietud (56:20). El manejo de estas recurrencias musicales, y especialmente la recapitulación de $\mathrm{CH}$ en la plaza de toros y de TA al final de la película, habría otorgado a la banda sonora de Carmen, la de Triana

devengados bajo el concepto "cine sonoro". En 1940, esta cantidad ascendió a 6.000 pesetas Véase Patria: diario de Falange Española Tradicionalista y de las J.O.N.S., año VI, núm. 1.240 (Granada, 14 de febrero de 1941), p. 3. 

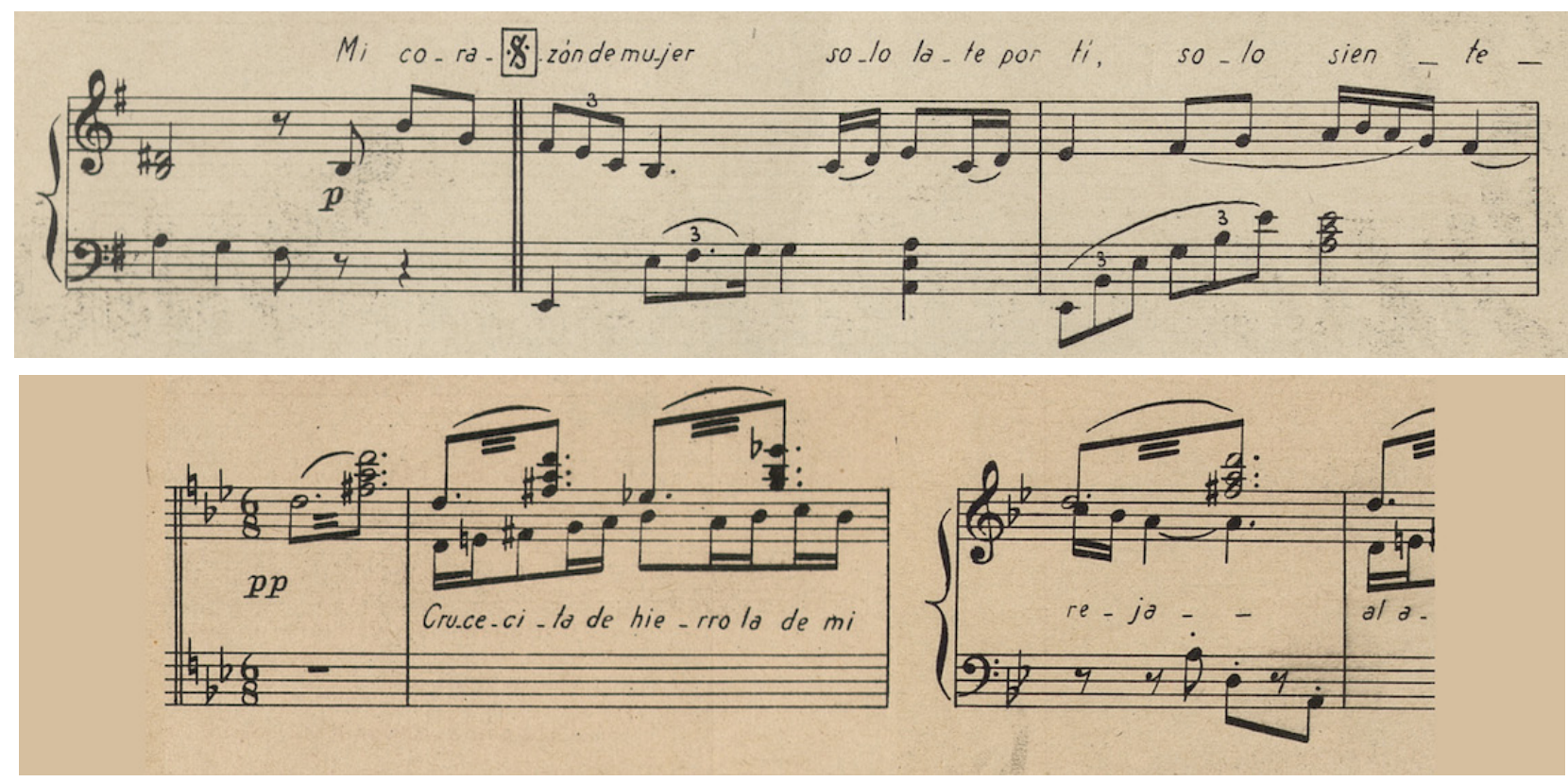

Ejemplo 9. Tema de amor (TA) arriba y "Crucecita de hierro" $(\mathrm{CH})$ abajo en la canción homónima de Muñoz Molleda. Fragmentos extraídos de José Muñoz Molleda. Crucecita de hierro (Ediciones Hispania, ca. 1950, Biblioteca Nacional, MP/1416/25).

el carácter de una sinfonía cíclica cuyos temas principales habrían sido expuestos al inicio y fueran revisitados al final, bajo una nueva luz impregnada de tragedia. La estructura de esta "sinfonía" habría sido:

I Movimiento (Exposición). TA, "Carceleras del puerto", "Los piconeros", "Antonio Vargas Heredia" (AV1, AV2).

II Movimiento (Adagio). "Noche de amor" (TA), "Triana, Triana".

III Movimiento (Desarrollo). Salida de prisión de Antonio Vargas, escena de la vieja gitana (TA), "Los piconeros”, TA (I), alucinaciones de José (retreta), TA en canon (II), "Crucecita de hierro" (CH), llegada de Antonio Vargas a Sevilla (AV1).

IV Movimiento (Recapitulación). Secuencia taurina (TA, CH), "Muerte de Vargas Heredia" (AV2), Marcha fúnebre (TA).

\subsubsection{La música de Carmen, la de Triana, de la estilización hollywoodiense al naturalismo castizo}

Como hemos visto, el cotejo del guion musical de Carmen, la de Triana contenido en MMolleda $\backslash 034$ con la banda sonora definitiva del filme arroja disparidades que, según adelantamos al principio del estudio, afectan a algo más de la mitad de la partitura recogida en el manuscrito. A excepción de algunas interpolaciones musicales y la abreviatura de algunas escenas, una gran cantidad de música extradiegética eliminada fue sistemáticamente sustituida o complementada por tres tipos principales de músicas: 1) los toques militares en todo lo concerniente al brigadier José y los dragones de Alcalá; 2) los pasodobles con respecto al torero Antonio Vargas durante la corrida de toros; y 3) los toques de guitarra flamenca (véase Tabla 5) en el caso de Carmen y su universo natural, los tablaos.

Del mismo modo que la eclosión de los toques militares sirvió para resaltar el conflicto de lealtades del brigadier con respecto al ejército, el terreno ganado por la guitarra flamenca y los pasodobles podría constituir un síntoma de un conflicto estético igualmente acuciante. Así, aunque el remplazo de la música de Muñoz Molleda por la guitarra flamenca - omnipresente, por lo demás, en las escenas de cafés y ventas - solo se produjo en una ocasión (en el bloque $n^{0} 7$ ), esta sustitución es significativa dado que la versión alemana del filme sí retuvo la música original. Esto es, a diferencia de muchos otros fragmentos musicales desestimados del guion musical que seguramente no llegaron siquiera a ser orquestados, esta sustitución de última hora podría atribuirse directa- 


\begin{tabular}{|l|l|l|}
\hline \multicolumn{1}{|c|}{ Minutaje } & \multicolumn{1}{|c|}{ Situación/descripción } & \multicolumn{1}{c|}{ Sustitución } \\
\hline $15: 57$ & Café del mulero. Antes de "Antonio Vargas Heredia” (D) & - \\
\hline $22: 02$ & Café del mulero. Después de “Antonio Vargas Heredia" (D) & - \\
\hline $47: 33$ & Café indeterminado. Antonio Vargas busca a Carmen (SD) & - \\
\hline $49: 24$ & $\begin{array}{l}\text { Taberna de Zahara. Carmen lee las cartas (SD) } \\
\text { Exterior de la taberna de Zahara. Encuentro furtivo entre Carmen y José (SD) }\end{array}$ & - \\
\hline $1: 04: 25$ & Taberna de Zahara. Carmen baila unas sevillanas (D) & - \\
\hline $1: 06: 52$ & $\begin{array}{l}\text { Exterior de la taberna de Zahara. Carmen canta en el interior, Antonio Vargas } \\
\text { reconoce su voz (SD) }\end{array}$ & - \\
\hline $1: 08: 39$ & Exterior de la taberna de Zahara. Antes de "Crucecita de hierro" (SD) & Bloque $\mathrm{n}^{\mathbf{0} 7}$ \\
\hline $1: 15: 30$ & Venta a las afueras de Sevilla. Baile de sevillanas (D) & - \\
\hline
\end{tabular}

Tabla 5. Relación de escenas con acompañamiento de guitarra flamenca en nivel diegético (D) o seudodiegético (SD).

mente a una decisión de Rey. Una situación semejante pero mucho más relevante- se produce con respecto al Finale sinfónico (bloque $\mathrm{n}^{\mathrm{o}} 10$ ), que también aparece en la versión alemana del filme, aunque en un lugar completamente distinto.$^{87}$ En este caso, la eliminación del punto de vista subjetivo y dinámico — como "comentarista de la acción"- de la partitura concebida por Muñoz Molleda para esta escena, a favor del naturalismo y la neutralidad expresiva de la música taurina, supone una enmienda total al lenguaje y los usos habituales en las bandas sonoras hollywoodienses.

Todas estas sustituciones apuntan a los delicados equilibrios que Rey debió atender al tratar un tema tan sensible en términos de identidad nacional como el de Carmen. Como sabemos, la gitana más universal fue motivo de fuerte controversia en España desde el estreno madrileño de la ópera de Bizet en 1887; espoleó numerosas reacciones desde diversas instancias musicales e intelectuales que se volvieron a repetir con cada una de sus adaptaciones al celuloide, ${ }^{88}$ incluida la versión de Rey. ${ }^{89}$ El director aragonés, defensor a ultranza de un cine de

${ }^{87} \mathrm{La}$ versión alemana del filme sigue los pasos de Rey en la escena de la corrida de toros haciendo uso de los pasodobles, pero aprovecha esta brillante composición casi en su totalidad presentándola al inicio de la película, desde la aparición de Carmen hasta que es repelida por el oficial a la entrada de la prisión. Como es esperable, en este nuevo contexto las referencias a TA y $\mathrm{CH}$ pierden todo su significado.

${ }^{88}$ Encontramos un resumen de estas reacciones (Pedrell, Bretón, Falla y Ernesto Halffter) en Michael Christoforidis, “Georges Bizet's 'Carmen' and Fin-de-Siècle Spanish National Opera”, Studia Musicologica, 52/1-4 (2011), pp. 419-428.

${ }^{89}$ Miranda, “A new Carmen for a new Spain”, pp.91-93. raíz folclórica, pero enemigo acérrimo de los tópicos hispánicos instalados en el imaginario internacional, ${ }^{90}$ debió transitar por un terreno plagado de minas que le obligó, además, a defenderse de las acusaciones de la crítica falangista de haber caído en la españolada: ${ }^{11}$

Rechazo la palabra españolada aplicada al costumbrismo y al folklore españoles. Mi Nobleza baturra, mi Morena Clara, mi Carmen la de Triana, mi Aldea maldita, mi Orosia, no son españoladas. [...] Españolada es la España que un extranjero recoge y presenta sin conocerla, sin haberla vivido, sin amarla como la conocemos, la vivimos y la amamos nosotros. ${ }^{92}$

Esta declaración, que sintetiza uno de los principales vectores de su credo estético, explica además que, pese a la diversidad de razones que pudieron inspirar los cambios operados en el guion original, todos ellos remaron, en última instancia, en una misma dirección: la erección de un modelo cinematográfico de españolidad - moral, narrativo, plástico, y también musical- que, contando con el folclorismo como principal sello de autenticidad, corrigiera la influencia distorsionadora que el cine extranjero había ejercido en estos ámbitos. Al haber aceptado llevar a la gran pantalla el mito de Carmen, el

${ }^{90}$ Con respecto al rodaje de Carmen, la de Triana, es sobradamente conocida la anécdota de que Florián Rey ordenó rediseñar los decorados preparados por el equipo artístico alemán, que tenía "la visión de una Andalucía de casa negras pobladas de cojos, mancos y tuertos"; véase Ruiz y Fiestas, Imperio Argentina, p. 49.

91 Sánchez Vidal, El cine de Florián Rey, pp. 241-243.

92 Florián Rey, "Españoladas", Vértice, año VII, núm. 71 (Madrid, febrero de 1944), pp. 46-48 y 81-82. 
director aragonés se sumaba además a la distinguida serie de artistas españoles que ofrecieron una alternativa a los estereotipos románticos trenzados alrededor de Andalucía, los gitanos, la sensualidad meridional y el amor fatal.

El filme The Devil is a Woman, dirigido por Josef von Sternberg y protagonizado por Marlene Dietrich, ofrece probablemente el ejemplo más elocuente de todo aquello que Florián Rey quiso enmendar en su propia Carmen. Esta película, exhibida en España en 1935 como Tu nombre es tentación, provocó una inédita ola de protestas en las oficinas madrileñas de la Paramount y en los cines de varias ciudades que se saldaron con algún incidente violento y un conflicto diplomático con los Estados Unidos. El origen de estas protestas fue, precisamente, la imagen caricaturesca que este filme ofrece de Andalucía y de sus habitantes: ${ }^{93}$ su protagonista, una seductora sin escrúpulos, despliega sus encantos en una Sevilla en perpetua fiesta, repleta de peinetas, serpentinas y confeti y abarrotada de gitanas, toreros, bandidos y guardias civiles con desproporcionados tricornios, incapaces de poner orden y hacerse respetar.

Florián Rey da la vuelta, uno por uno, a todos estos estereotipos, y así, frente a la perversión y la doblez de la rubia Conchita/Dietrich, contrapone la integridad de la morena Carmen/Argentina; frente al abigarrado pintoresquismo del carnaval sevillano (sic), la luminosa ambientación andalucista de Juan Laffita Díaz; ${ }^{94}$ frente al retrato grotesco e inoperante de la guardia civil, la dignidad y el alto sentido del honor de los dragones de Alcalá y, no menos importante, frente al hispanismo franquiciado del Capriccio espagnol de Rimski-Kórsakov (una de las obras que conforman la banda sonora de esta película), la autenticidad de la guitarra flamenca, los pasodobles taurinos y la copla de Juan Mostazo ennoblecida por las orquestaciones de Muñoz Molleda. Estas facetas ofrecen, junto al sobrio andalucismo de la partitura del compositor linense, una panorámica de la música española en la que se enhebran sin sobresaltos sus facetas folclórica, popular y seria.

\footnotetext{
93 Sobre la recepción de esta película en España, puede consultarse Hilaria Loyo Gómez, "En la estela de Carmen: Marlene Dietrich en 'The Devil is a Woman'", Archivos de la filmoteca. Revista de estudios históricos sobre la imagen, 51 (2005), pp. 48-65 y María Sánchez Cabrera, "The Devil is a Woman y el Bienio Conservador (1933-1935)", Cultura de la República. Revista de análisis crítico, 2 (2018), pp. 95-112.

94 Juan Laffita Díaz, director del Museo Arqueológico sevillano, colaboró en la película como supervisor artístico y ambientador; véase Sánchez Vidal, El cine de Florián Rey, p. 231.
}

\section{CONCLUSIONES}

El cotejo de las fuentes musicales de Carmen, la de Triana con las bandas sonoras de las versiones española y alemana del filme ha proporcionado pistas únicas y significativas (aunque no siempre concluyentes) acerca de su proceso creativo. De este proceso hemos obtenido evidencias acerca de la eliminación o reestructuración de escenas con respecto a un guion original perdido, pero también ha ofrecido numerosos indicios acerca del propósito artístico de ciertas decisiones y de sus implicaciones estéticas e ideológicas.

De especial interés ha sido descubrir los cauces de la filiación republicana de la zambra "Antonio Vargas Heredia" de la que dependen algunos elementos de la trama. El carácter circunstancial de estos cauces apunta a una temprana filtración en la incipiente cultura franquista del andalucismo lorquiano que acabará por constituir, en una versión domesticada y convencionalizada, uno de los rasgos identitarios del nuevo régimen.

El estudio de la partitura original de Muñoz Molleda nos ofrece una aproximación a la música, aún escasamente estudiada, de este autor. Aunque, por su carácter vicario y dependencia de múltiples factores exógenos, la música cinematográfica no pueda considerarse representativa de la estética de un compositor, los parentescos estilísticos identificados en el manuscrito MMolleda\034 han apuntado a fuentes tan diversas como la zarzuela, el verismo, la música rusa y un incipiente neocasticismo, todas ellas revestidas de un sobrio pero inequívoco andalucismo. Unas coordenadas similares a las que establece Gemma Pérez Zalduondo con respecto a los primeros años de la posguerra del compositor - “orientación neoclásica, aunque enmarcada en un nacionalismo de carácter específicamente andaluz"-,${ }^{95}$ impregnadas si acaso de una mayor variedad y colorido como resultado de las particularidades del medio cinematográfico.

Finalmente, el análisis de los cortes efectuados, los añadidos de toques militares, la sustitución de algunas estampas musicales por músicas flamencas y taurinas, así como las diferencias en el aprovechamiento de la música original en la versión española del filme con respecto a la alemana, han ofrecido importantes pistas acerca de la

\footnotetext{
95 Gemma Pérez Zalduondo, "De la tradición a la vanguardia: música, discursos e instituciones desde la Guerra Civil hasta 1956", en Historia de la Música Española e Hispanoamericana, 7: La música en España en el siglo XX, ed. Alberto González Lapuente (Madrid: Fondo de Cultura Económica, 2012), p. 125.
} 
evolución "sobre la marcha" del proyecto cinematográfico. Estas pistas - cuya interpretación trasciende ampliamente el ámbito estrictamente musical - apuntan a una deliberada pérdida de centralidad de la protagonista a lo largo de este proceso que afectó especialmente a la segunda mitad del metraje, especialmente a través de la reducción y cambio de foco en el episodio de la vieja gitana y el remplazo del componente melodramático de la secuencia taurina por el neutro naturalismo de los pasodobles. También revelan el incremento de peso de la vertiente política de la trama a través de la inserción de fanfarrias de sonoridad "imperial" y la potenciación de la crisis interna de José en la escena de las alucinaciones, hasta convertir esta cuestión en el verdadero nudo de la película. Dicho en forma simplificada: el conflicto que, al inicio del rodaje, aún pivotaba sobre la decisión de Carmen - el militar o el torero-, terminó haciéndolo sobre la decisión del brigadier - la gitana o el ejército-.

Más allá de estas extrapolaciones, las decisiones tomadas a lo largo de la gestación de Carmen, la de Triana ponen de relieve la existencia en este filme de un objetivo y unos estándares de calidad y congruencia musical que lo distingue, sin ir más lejos, de la rutinaria y en lo musical inconsecuente versión alemana dirigida por Herbert Maisch: el equilibrio entre los elementos populares, cultos y folclóricos como una baza crucial en la satisfacción del ideario estético — españolista, pero con afán internacionalista; tradicionalista, pero dirigido al mercado capitalista; ficcional, pero sin renunciar a la autenticidaddel cine de Florián Rey.

\section{APÉNDICES}

APÉNDICE 1. Manuscritos incluidos en la carpeta "Carmen, la de Triana" perteneciente al Fondo José Muñoz Molleda del Centro de Documentación y Archivo (CEDOA) de la Sociedad General de Autores y Editores (SGAE) en Madrid.

\begin{tabular}{|c|c|c|c|}
\hline Signatura & Título (sic.) & $\begin{array}{c}\text { Contenido } \\
\end{array}$ & $\begin{array}{l}\text { Descripción } \\
\end{array}$ \\
\hline MMolleda $\backslash 034$ & Carmen la de Triana & $\begin{array}{l}\text { Guion pianístico (a tres } \\
\text { pentagramas) de la banda } \\
\text { sonora completa. }\end{array}$ & $\begin{array}{l}9 \text { pliegos, } 36 \text { páginas, } 18 \\
\text { pentagramas/página (K.U.V. } \\
\text { Beethoven Papier Nr.34). }\end{array}$ \\
\hline MMolleda $\backslash 035$ & $\begin{array}{l}\text { "Los Piconeros" (Bulerías } \\
\text { siglo XVIII). Del film } \\
\text { "Carmen la de Triana" }\end{array}$ & $\begin{array}{l}\text { Guion pianístico (a dos } \\
\text { pentagramas) de la canción } \\
\text { "Los piconeros" sin letra. }\end{array}$ & $\begin{array}{l}1 \text { pliego, } 4 \text { páginas, } 12 \\
\text { pentagramas/página. }\end{array}$ \\
\hline MMolleda $\backslash 036$ & $\begin{array}{l}\text { "Carceleras del Puerto". Del } \\
\text { film "Carmen la de Triana" }\end{array}$ & $\begin{array}{l}\text { Guion pianístico (a dos } \\
\text { pentagramas) de la canción } \\
\text { "Carceleras del Puerto" sin } \\
\text { letra. Poema completo al final. }\end{array}$ & $\begin{array}{l}1 \text { pliego, } 4 \text { páginas, } 18 \\
\text { pentagramas/página (K.U.V. } \\
\text { Beethoven Papier Nr. } 34) \text {. }\end{array}$ \\
\hline MMolleda $\backslash 037$ & $\begin{array}{l}\text { "Antonio Vargas" (Pasodoble } \\
\text { del film "Carmen"). Música } \\
\text { de Muñoz Molleda y Juan } \\
\text { Mostazo }\end{array}$ & $\begin{array}{l}\text { Guion pianístico (a dos } \\
\text { pentagramas) del pasodoble } \\
\text { "Antonio Vargas Heredia". }\end{array}$ & $\begin{array}{l}1 \text { pliego, } 4 \text { páginas, } 12 \\
\text { pentagramas/página. }\end{array}$ \\
\hline MMolleda $\backslash 038$ & $\begin{array}{l}\text { "Triana... Triana". Canción } \\
\text { de la película "Carmen". Letra } \\
\text { de A. García Padilla y F. Rey. } \\
\text { Música de Muñoz Molleda y } \\
\text { Mostazo }\end{array}$ & $\begin{array}{l}\text { Guion pianístico (a dos } \\
\text { pentagramas) de la canción } \\
\text { "Triana, Triana" sin letra. }\end{array}$ & $\begin{array}{l}1 \text { pliego, } 4 \text { páginas, } 12 \\
\text { pentagramas/página (Sünova } \\
\text { Nr. } 4 \text { ). }\end{array}$ \\
\hline MMolleda\s.n. (1) & Sin título & $\begin{array}{l}\text { Melodías con letra de las } \\
\text { canciones "Los piconeros", } \\
\text { "Antonio Vargas Heredia", } \\
\text { "Crucecitas de hierro", } \\
\text { "Muerte de Antonio Vargas" y } \\
\text { "Triana, Triana". }\end{array}$ & $\begin{array}{l}1 \text { pliego, } 4 \text { páginas, } 16 \\
\text { pentagramas/página (Durand } \\
\& \text { Cie. } 4 \text {, Place de la } \\
\text { Madeleine, Paris). }\end{array}$ \\
\hline MMolleda\s.n. (2) & Sin título & $\begin{array}{l}\text { Partitura orquestal (a nueve } \\
\text { pentagramas) de la canción } \\
\text { "Carceleras del Puerto" sin } \\
\text { letra. }\end{array}$ & $\begin{array}{l}2 \text { pliegos apaisados, } 8 \text { páginas, } \\
18 \text { pentagramas/página }\end{array}$ \\
\hline
\end{tabular}




\section{APÉNDICE 2. EJEMPLOS MUSICALES.}
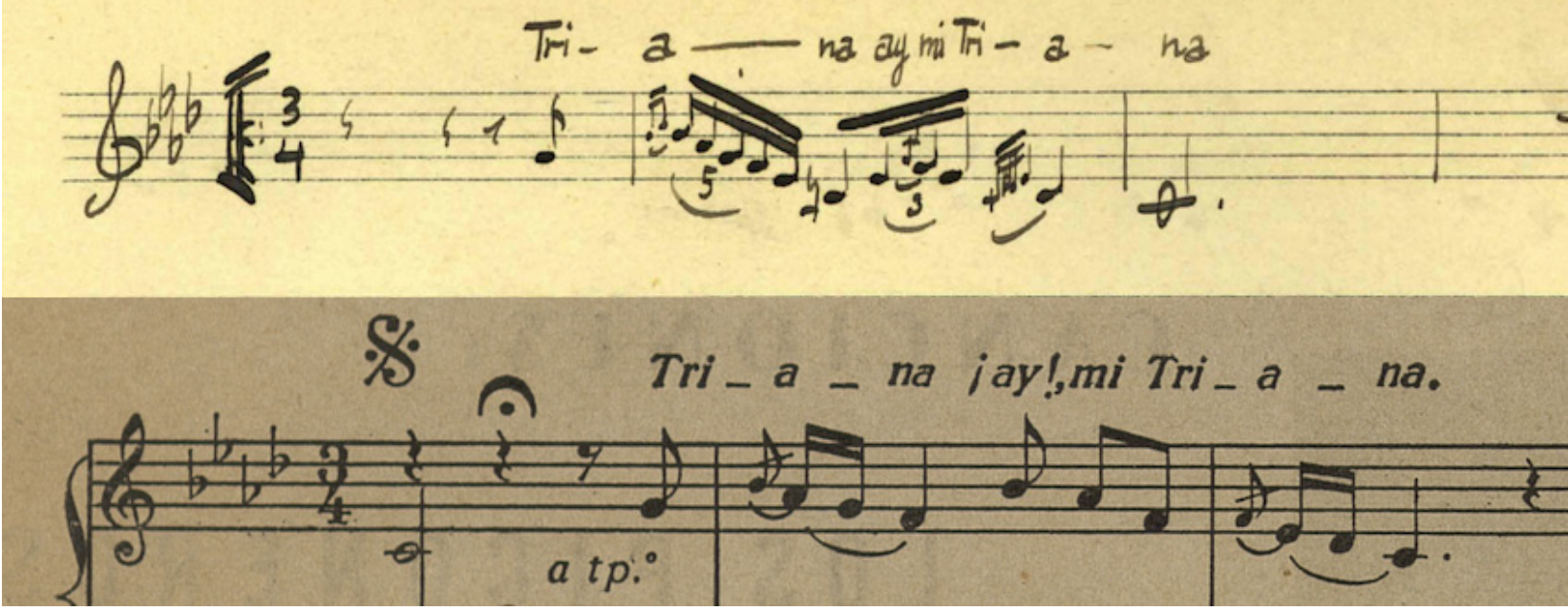

1. Inicio de la canción "Triana, Triana". Arriba, la versión de MMolleda s.n. (1), idéntica a la de MMolledal038. "Escenas 1-3", cc. 8-19 (MMolleda\034, p. 4). Abajo, en Juan Mostazo. ¡Triana, Triana!, canción andaluza del film Carmen la de Triana (Música Moderna, ca. 1940, Biblioteca Nacional, MP/5901/41). La versión definitiva es sensiblemente más sencilla que la original.

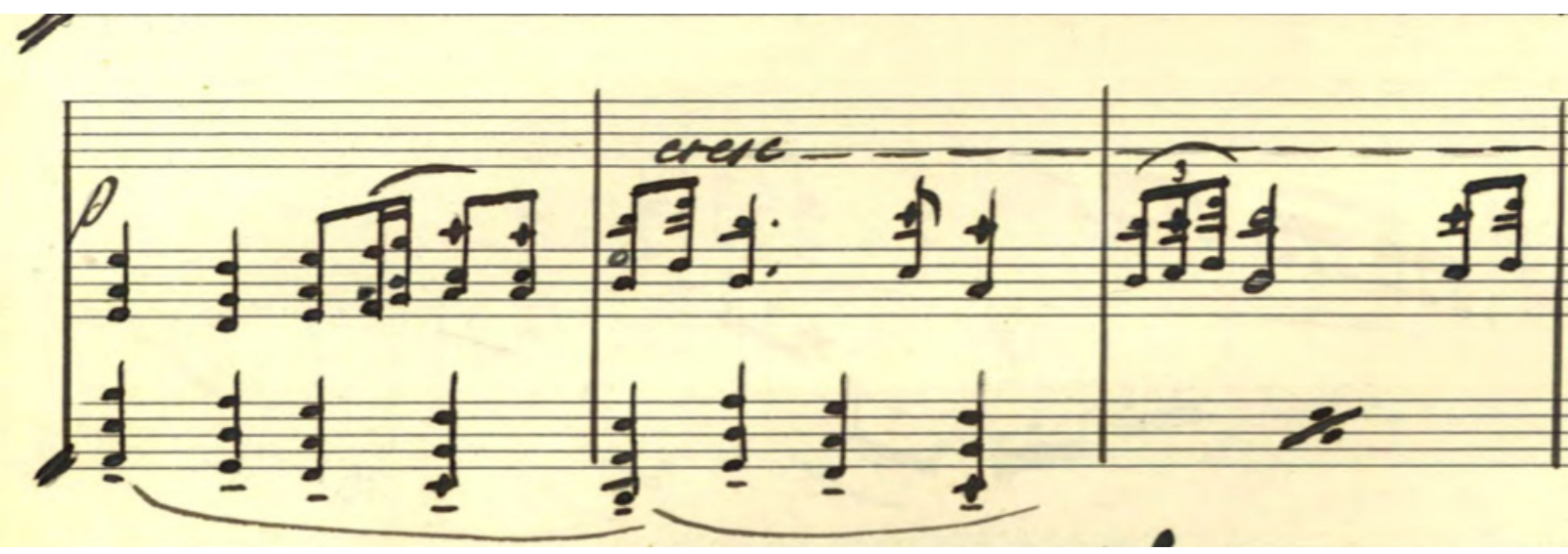

2. "Escena 65", cc. 5-7 (MMolleda\034, p. 15). Ejemplo de mixturas de quintas paralelas evocadoras de la pesadumbre durante el camino de Carmen hasta la cueva de la vieja gitana. 


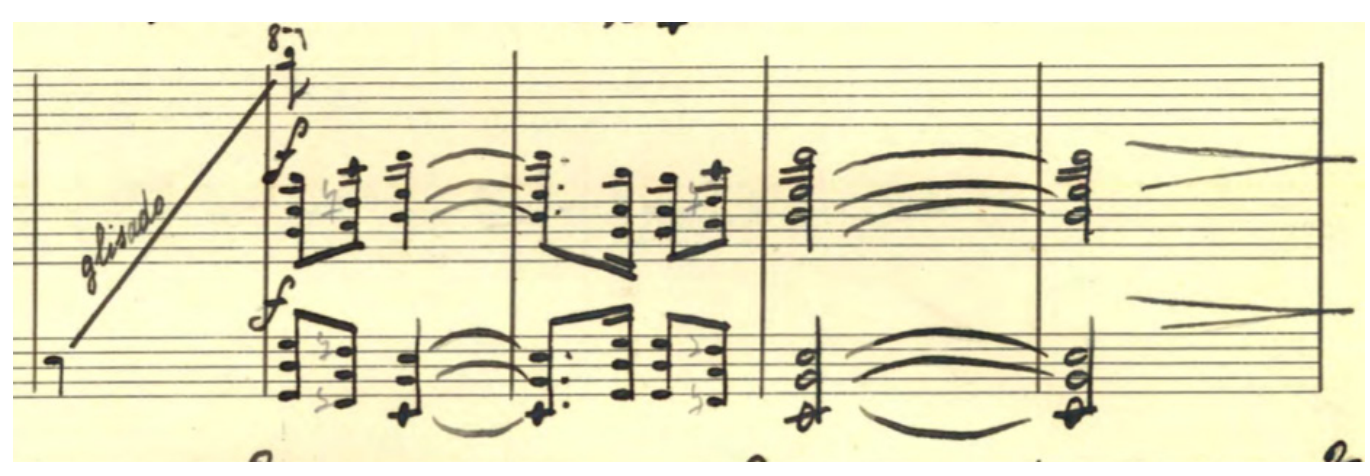

3. "Escena 70 al 89", cc. 32-36 (MMolleda 1034 , p. 19). Ejemplo de mixturas de quintas paralelas evocadoras de la magia y el terror durante la escena de la vieja gitana.

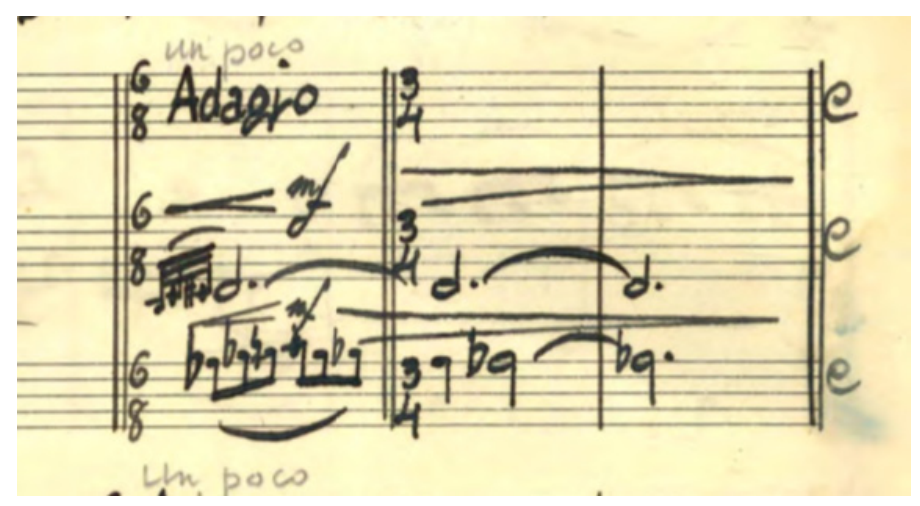

4. "Escena 70 al 89", cc. 7-9 (MMolleda\034, p. 18). Este motivo cromático ("motivo de la magia 1") aparece hasta en tres ocasiones más durante esta sección (cc. 13-15, 20-23 y 82-84) en respuesta a las nerviosas figuras de las secciones "Andante rítmico", pero desaparece por completo en el metraje definitivo de la película.

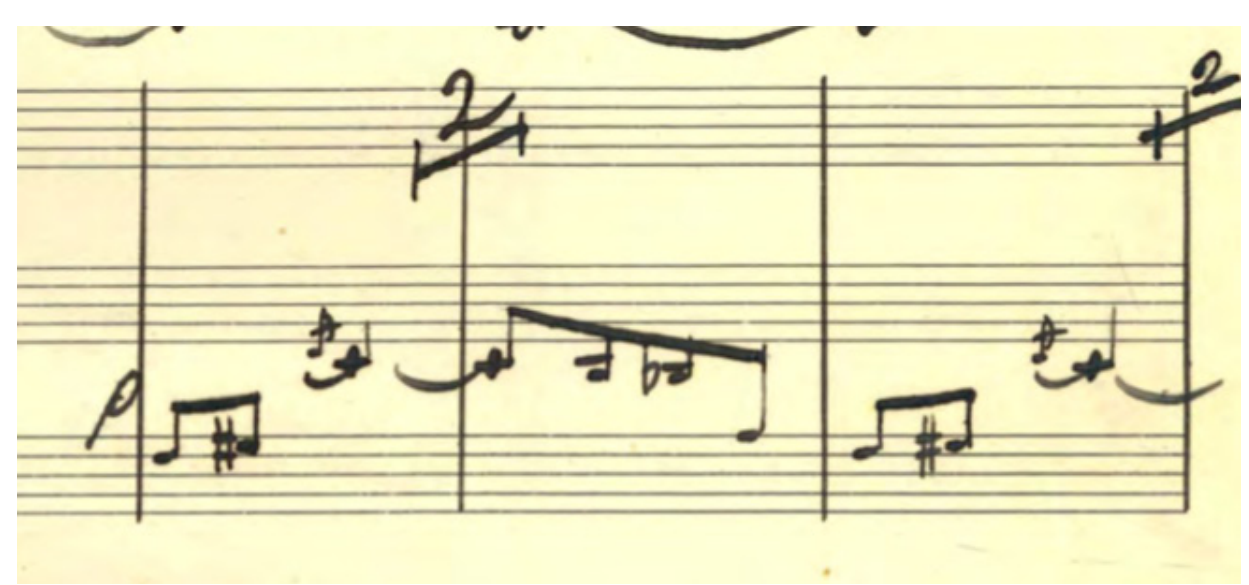

5. "Escena 70 al 89", cc. 41-43 (MMolledal034, p. 19). Este motivo cromático ("motivo de la magia 2") se encuentra también en la porción conservada en el metraje definitivo de la película ("Escena 70 al 89", cc. 95-96 y sucesivos). 


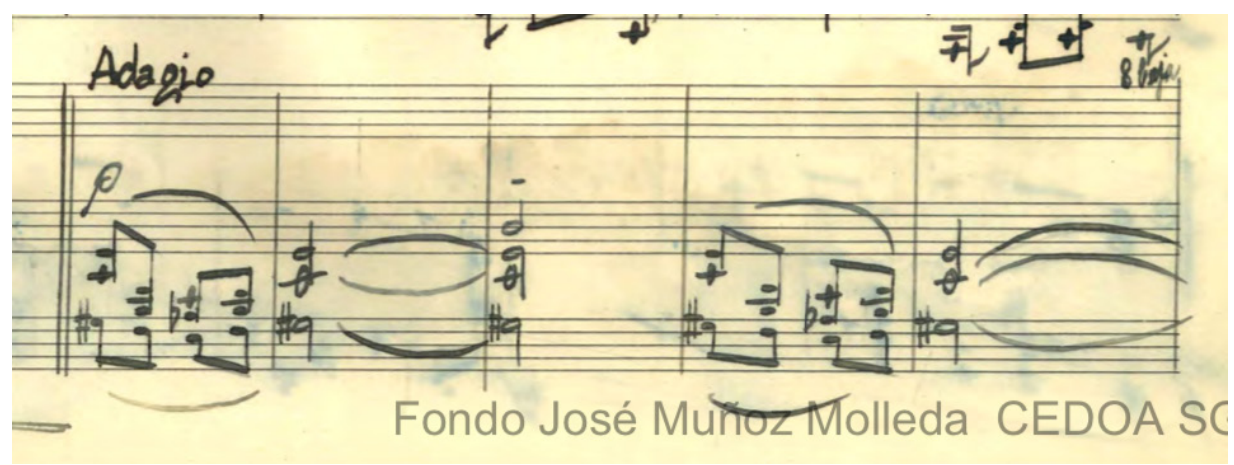

6. "Escena 70 al 89”, cc. 60-64 (MMolleda\034, p. 19). Pasaje con acumulación de tríadas aumentadas en la escena de la vieja gitana.

APÉNDICE 3. Discografía histórica (78 r.p.m.)

Dada la disparidad de fuentes utilizadas para recopilar esta discografía histórica, y su variable grado de precisión, algunas referencias aparecen incompletas.

Estructura de las referencias:

Intérpretes y otra información incluida en el prensado. Sello, núm. de catálogo (núm. de matriz). Lugar de grabación, año de grabación.

"Antonio Vargas Heredia" (pasodoble).

1. Tejada y su Gran Orquesta. Iberia, C-3181-A (C1-4330). Columbia A 2567.

2. Will Glahé Orchestra; Juan M. Merenciano. Victor $(\mathrm{V}-165 \mathrm{~B})$.

"Antonio Vargas Heredia" (zambra).

3. Adelita Trujillo, Rafael de Paz, Mostazo, Molleda, Oliva, Rey. RCA Victor 75966-B. 1939.

4. Conchita Piquer, M. Lizcano de la Rosa. Odeon 184.425 (SO 8939). Barcelona, 1940.

5. Consuelo Moreno, J. de Oliva-Mostazo. Decca 21076 A (66588AA).

6. Estrellita Castro. Gran Orquesta Columbia. Columbia R 6024 (C 4625). Iberia C-3192-A (C 4625). 1942.

7. Imperio Argentina. Hansom Milde-Meißner mit Orchestra. Grammophon 30036 B (7978 1/2 GD 8). Berlín, $1938 .{ }^{96}$

96 Wolfgang Schneidereit: Discographie der Gesangsinterpreten der leichten Muse von 1925 bis 1945 im deutschsprachi-
8. Paz Monroy. Tejada y su Gran Orquesta. Columbia V 2547 (C 4323).

"Carceleras del Puerto" (bulerías).

9. Conchita Piquer, Melchor de Marchena. Odeon 184.437 (SO 8941). Barcelona, 1940.

10. Delia Vasquez acompañada de guitarras: García y Manzanos. France Odéon 279.571 (KI 8826).

11. Estrellita Castro. Gran Orquesta Columbia. Columbia R 6025 (C 4541). 1942.

12. Imperio Argentina. Hansom Milde-Meißner mit Orchestra. Grammophon. Berlín, 1938.

\section{"Crucecita de hierro".}

13. Imperio Argentina. Gran Orquesta Columbia, Muñoz Molleda; F. Rey. Iberia C-3144-A (C 5262). Columbia S 250-A (C 5262). San Sebastián, 1942.

\section{"La muerte de Vargas Heredia".}

14. Imperio Argentina. Hansom Milde-Meißner mit Orchestra. Grammophon 30037 B (7980 1⁄2 GD 8). Berlín, 1938.

"Los Piconeros" (pasodoble).

15. Tejada y su Gran Orquesta. Columbia, A 2566. ${ }^{97}$

"Los Piconeros" (bulerías del siglo XVIII).

16. Adelita Trujillo, Rafael de Paz, Mostazo, Molleda, Perrello. RCA Victor 75966-A. 1939.

gen Raum. Band 2: Kirsten Heiberg bis Ethel Reschke. Norderstedt, BoD, 2019, p. 637.

${ }^{97}$ https://issuu.com/78rpm.club/docs/columbia_records_-cat_logo_genera. 
17. Conchita Piquer, M. Lizcano de la Rosa. Odeon 184.425 (SO 8938). Barcelona: 1940.

18. Delia Vasquez acompañada de guitarras: García y Manzanos. France Odéon 279.571 (KI 8827).

19. Estrellita Castro. Gran Orquesta Columbia. Columbia R 6024 (C 4627).

20. Imperio Argentina. Hansom Milde-Meißner mit Orchestra. Grammophon 30036 A (B 7977 1/2 GD 8). Berlín, 1938.

21. Miguel Herrero, Paco Millet y Manuel Medina, Leon, Quiroga. SMC 1250-A (140 194).

22. Niño Ricardo y Melchor de Marchena. Bulerías sobre motivos de Los Piconeros, de la película, Carmen la de Triana. Juan Mostazo. Odeon 184.807 (SO 8898). Barcelona, 1951.
23. Paz Monroy. Tejada y su Gran Orquesta. Columbia V 2547 (C 4392).

\section{"Toros en Jerez" (pasodoble).}

24. Tejada y su Gran Orquesta. Iberia, C-3181-B (C1-4331). Columbia A 2567 (C1-4331).

"Triana, Triana" (zambra).

25. Imperio Argentina. Gran Orquesta dirigida por Guillermo Cases. Juan Mostazo, José Muñoz Molleda, Antonio García Padilla, Antonio Martínez del Castillo. Odeon Argentina 56006 A (16709).

26. Imperio Argentina. Hansom Milde-Meißner mit Orchestra. Grammophon 30037 A (B 7979 1/2 GD 8). Berlín, 1938.

APÉNDICE 4. Créditos de las canciones de Carmen, la de Triana.

\begin{tabular}{|l|l|l|}
\hline \multicolumn{1}{|c|}{ Canción } & \multicolumn{1}{|c|}{ Compositor } & \multicolumn{1}{c|}{ Letrista } \\
\hline "Carceleras del Puerto" & $\begin{array}{l}\text { Juan Mostazo } \\
\text { [Imperio Argentina }]\end{array}$ & Joaquín de la Oliva \\
\hline "Los piconeros" & Juan Mostazo & Ramón Perelló \\
\hline "Antonio Vargas Heredia" & $\begin{array}{l}\text { Juan Mostazo } \\
\text { Francisco Merenciano }\end{array}$ & $\begin{array}{l}\text { Joaquín de la Oliva } \\
\text { Florián Rey }\end{array}$ \\
\hline "Triana, Triana" & $\begin{array}{l}\text { Juan Mostazo } \\
\text { Florián Rey }\end{array}$ \\
\hline "La muerte de Vargas Heredia" & $\begin{array}{l}\text { Juan Mostazo } \\
\text { [Imperio Argentina }]\end{array}$ & $\begin{array}{l}\text { Joaquín de la Oliva } \\
\text { Florián Rey }\end{array}$ \\
\hline "Crucecita de hierro" & José Muñoz Molleda & $\begin{array}{l}\text { Florián Rey } \\
\text { José Muñoz Molleda }\end{array}$ \\
\hline
\end{tabular}

\section{BIBLIOGRAFÍA CITADA}

Altman, Rick. The American Film Musical. Bloomington, IN: Indiana University Press, 1987.

Álvarez Berciano, Rosa y Ramón Sala Noguer. El cine en la zona nacional (1936-1939). Bilbao: Ediciones Mensajero, 2000.

Barreira, Domingo F. Biografía de Florián Rey. Madrid: Agrupación Sindical de Directores-Realizadores Españoles de Cinematografía, 1968.

Benet, Vicente J. El cine español. Una historia cultural. Barcelona: Paidós Ibérica, 2012. . "Tipologías del estrellato durante el franquismo: algunas fórmulas dominantes". Cinema Compart/ Ive Cinema, 5/10 (2017), pp. 29-30.
Caparrós Lera, José María. Arte y política en el cine de la República (1931-1939). Barcelona: Universidad de Barcelona, Editorial 7 1/2, 1981.

Christoforidis, Michael. 'Georges Bizet's 'Carmen' and Fin-de-Siècle Spanish National Opera”. Studia Musicologica, 52/1-4 (2011), pp. 419-428.

Claver Esteban, José María. Luces y rejas. Estereotipos andaluces en el cine costumbrista español (18961939). Sevilla: Fundación Pública Andaluza Centro de Estudios Andaluces, 2012.

Cobo Guzmán, Eugenio. El flamenco en el cine. Sevilla: Signatura Ediciones de Andalucía, 2013.

Company, Juan Miguel. "La cruzada del brigadier". Archivos de la Filmoteca de la Generalitat Valenciana, 7 (1990), pp. 14-19.

De La Plaza, Martín. Imperio Argentina. Una vida de artista. Madrid: Alianza Editorial, 2003. 
De Molina, Miguel. Botín de Guerra. Autobiografia. Barcelona: Planeta, 1998.

Díez Puertas, Emeterio. "Los acuerdos cinematográficos entre el franquismo y el Tercer Reich (1936-1945)". Archivos de la Filmoteca. Revista de estudios históricos sobre la imagen. Segunda época, 33 (1999), pp. 34-59.

. "El montaje del Franquismo: la política cinematográfica de las fuerzas sublevadas". Cuadernos de Historia Contemporánea, 23 (2001), pp. 141-157.

"Diez años después de Morena Clara, entrevista a Florián Rey", Primer plano. Revista española de cinematografía, año V, núm. 174. Madrid, 13 de febrero de 1944, pp. 7-8.

Fraile, Teresa. "Música de cine en España. Crecimiento y consolidación de una disciplina". La Albolafia. Revista de Humanidades y Cultura, 9 (2016), pp. 11-30.

García Soriano, Esther. "La música en el cine español de la posguerra (1939-1950)". Tesis doctoral, Universidad Complutense de Madrid, 2014.

Gubern, Román. El cine sonoro en la II República 19291936. Historia del cine español II. Barcelona: Editorial Lumen, 1977.

Jover Oliver, Rafael. "Andalucía desde Berlín: Carmen la de Triana". En Andalucía: una civilización para el cine, coordinado por Francisco Perales Bazo. Sevi1la: Padilla libros, 2001, pp. 13-34.

. "Una 'Carmen' alemana. El cine español y la Alemania nazi”. mAGAzin. Revista de Germanistica Intercultural, 11 (2002), pp. 74-81.

Labanyi, Jo. Lo andaluz en el cine del franquismo: los estereotipos como estrategia para manejar la contradicción. Sevilla: Fundación Centro de Estudios Andaluces, centrA, 2003.

López Gómez, Lidia. "La composición musical para el cine en la guerra civil española. Música, política y propaganda en cortometrajes y mediometrajes (1936-1939)". Tesis doctoral, Universitat Autònoma de Barcelona, 2014.

López González, Joaquín. "Música y cine en la España del franquismo: el compositor Juan Quintero Muñoz (1903-1980)". Tesis doctoral, Universidad de Granada, 2009.

Loyo Gómez, Hilaria. "En la estela de Carmen: Marlene Dietrich en 'The Devil is a Woman"'. Archivos de la filmoteca. Revista de estudios históricos sobre la imagen, 51 (2005), pp. 48-65.

Meseguer, Manuel Nicolás. La intervención velada: el apoyo cinematográfico alemán al bando franquista (1936-1939). Murcia: Universidad de Murcia, 2004.
. Hispano Film Produktion. Una aventura españolista en el cine del Tercer Reich (1936-1944). Santander: Shangrila, 2017.

Miranda, Laura. "La música en el cine policiaco de Edgar Neville. Del cosmopolitismo hollywoodiense al casticismo de posguerra. Propuesta de análisis audiovisual". Revista de Musicología, 32/2 (2009), pp. 687-702.

. "Manuel Parada y la música cinematográfica española durante el franquismo: estudio analítico". Tesis doctoral, Universidad de Oviedo, 2011.

Canciones en el cine español. Periodo de autarquía (1939-1950). Santander: Shangrila, 2018.

. "A new Carmen for a new Spain: nationalism and cinema during the Spanish Civil War". En Experiencing Music and Visual Cultures. Threshold, Intermediality, Synchresis, editado por Antonio Cascelli y Denis Condon. Abingdon: Routledge, 2021, pp. 91-103.

Muñoz Aunión, Marta. "El cine español según Goebbels: apuntes sobre la versión alemana de Carmen, la de Triana". En El espiritu del caos. Representación y recepción de las imágenes durante el Franquismo, coordinado por Laura Gómez Vaquero y Daniel Sánchez Salas. Madrid: Ocho y Medio, 2009, pp. 21-62.

Nile del Río, Magdalena [Imperio Argentina] y Pedro Manuel Víllora. Imperio Argentina. Malena Clara. Madrid: Ediciones Temas de Hoy, 2001.

Pardo Ballester, Trinidad. "Flamenco: orientalismo, exotismo y la identidad nacional española", vol. 1. Tesis doctoral, Washington, Georgetown University, 2007.

Pérez Rufí, Jose Patricio y Francisco Gómez Pérez. "La producción cinematográfica en Andalucía durante la Guerra Civil". Historia y Comunicación Social, 22/1 (2017), pp. 89-101.

Pérez Zalduondo, Gemma. El compositor José Muñoz Molleda: de la Generación del 27 al franquismo. Almería: Zéjel Editores, 1989.

. "De la tradición a la vanguardia: música, discursos e instituciones desde la Guerra Civil hasta 1956". En Historia de la Música en España e Hispanoamérica, 7: La música en España en el siglo XX, editado por Alberto González Lapuente. Madrid: Fondo de Cultura Económica, 2012, pp. 101-167.

Pineda Novo, Daniel. Rafael de León, un hombre de copla. Torredonjimeno: Editorial Almuzara, 2012.

Ródenas Rozas, Francisco José. "Especial: Ramón Perelló". Revista La Flamenca, 28 (2009) 
$<$ https://www.revistalaflamenca.com/reportajeramon-perello/> [consulta: 12/01/2021].

Roldán Garrote, David. "Fuentes documentales para el estudio de la música en el cine español de los años 40". Tesis doctoral, Universidad Politécnica de Valencia, 2003.

Ruiz, José y Jorge Fiestas. Imperio Argentina. Ayer hoy y siempre. Sevilla: Argantonio, Ediciones Andaluzas, 1981.

Sánchez Cabrera, María. "The Devil is a Woman y el Bienio Conservador (1933-1935)". Cultura de la República. Revista de análisis crítico, 2 (2018), pp. 95-112.

Sánchez Vidal, Agustín. El cine de Florián Rey. Zaragoza: Caja de Ahorros de la Inmaculada, 1991.

Slowik, Michael James. "Hollywood film music in the early sound era, 1926-1934". Tesis doctoral, University of Iowa, 2012.
Woods Peiró, Eva. White Gypsies. Race and Stardom in Spanish Musicals. Minneapolis y Londres: University of Minnesota Press, 2012.

Yraola, Aitor. “'Misión españolista': los camaradas Florián e Imperio con Hitler y el Dr. Goebbels". FILMHISTORIA Online, 9/3 (1999) < https://revistes. ub.edu/index.php/filmhistoria/article/view/12380> [consulta: 18/01/2020].

Zierer Meliá, Sylvia. "Carmen la de Triana". En Antología crítica del cine español, ed. Julio Pérez Perucha. Madrid: Filmoteca Española / Cátedra, 1997, pp. 116-118.

Recibido: 14.04.2021

Aceptado: 21.06.2021 